\title{
InSAR time series analysis of seasonal surface displacement dynamics on the Tibetan Plateau
}

\author{
Eike Reinosch $^{1}$, Johannes Buckel ${ }^{2}$, Jie Dong ${ }^{3}$, Markus Gerke ${ }^{1}$, Jussi Baade ${ }^{4}$, and Björn Riedel ${ }^{1}$ \\ ${ }^{1}$ Institute of Geodesy and Photogrammetry, Technische Universität Braunschweig, Braunschweig, Germany \\ ${ }^{2}$ Institute of Geophysics and extraterrestrial Physics, Technische Universität Braunschweig, Braunschweig, Germany \\ ${ }^{3}$ School of Remote Sensing and Information Engineering, Wuhan University, Wuhan, China \\ ${ }^{4}$ Department of Geography, Friedrich-Schiller-Universität Jena, Jena, Germany
}

Correspondence: Eike Reinosch (e.reinosch@tu-braunschweig.de)

Received: 5 November 2019 - Discussion started: 11 December 2019

Revised: 15 April 2020 - Accepted: 28 April 2020 - Published: 26 May 2020

\begin{abstract}
Climate change and the associated rise in air temperature have affected the Tibetan Plateau to a significantly stronger degree than the global average over the past decades. This has caused deglaciation, increased precipitation and permafrost degradation. The latter in particular is associated with increased slope instability and an increase in masswasting processes, which pose a danger to infrastructure in the vicinity. Interferometric synthetic aperture radar (InSAR) analysis is well suited to study the displacement patterns driven by permafrost processes, as they are on the order of millimeters to decimeters. The Nyainqêntanglha range on the Tibetan Plateau lacks high vegetation and features relatively thin snow cover in winter, allowing for continuous monitoring of those displacements throughout the year. The short revisit time of the Sentinel-1 constellation further reduces the risk of temporal decorrelation, making it possible to produce surface displacement models with good spatial coverage. We created three different surface displacement models to study heave and subsidence in the valleys, seasonally accelerated sliding and linear creep on the slopes. Flat regions at Nam Co are mostly stable on a multiannual scale but some experience subsidence. We observe a clear cycle of heave and subsidence in the valleys, where freezing of the active layer followed by subsequent thawing cause a vertical oscillation of the ground of up to a few centimeters, especially near streams and other water bodies. Most slopes of the area are unstable, with velocities of 8 to $17 \mathrm{~mm} \mathrm{yr}^{-1}$. During the summer months surface displacement velocities more than double on most unstable slopes due to freeze-thaw processes driven by higher temperatures and increased precipitation.
\end{abstract}

Specific landforms, most of which have been identified as rock glaciers, protalus ramparts or frozen moraines, reach velocities of up to $18 \mathrm{~cm} \mathrm{yr}^{-1}$. Their movement shows little seasonal variation but a linear pattern indicating that their displacement is predominantly gravity-driven.

\section{Introduction}

Permafrost describes subsurface material with a temperature of $0^{\circ} \mathrm{C}$ or lower for at least 2 consecutive years (French, 2017). Permafrost is covered by the active layer, which freezes and thaws seasonally (Shur et al., 2005). This causes frost heave and subsidence of wet ground on the order of centimeters due to the volume change associated with the ice-water phase transition. The amplitude of this heave-andsubsidence cycle is dependent on the water content of the active layer and the material of the ground (Matsuoka et al., 2003). On permafrost slopes the freezing and thawing of the active layer reduces slope stability (Zhang and Michalowski, 2015) and might create solifluction lobes (Matsuoka, 2001). Further examples of creeping landforms associated with permafrost are rock glaciers (Haeberli et al., 2006) and protalus ramparts (Whalley and Azizi, 2003).

The Tibetan Plateau (TP) has been the object of many studies focusing on climate change over the past decades, especially since it has become known that its temperature has risen significantly faster than the global average with a rate of $0.25^{\circ} \mathrm{C}$ per decade (Yao et al., 2000). This issue is exacerbated by the importance of the TP as a source of fresh water 
for large parts of greater Asia (Messerli et al., 2004). The TP is often referred to as the "Third Pole", as it carries the largest volume of frozen fresh water after the North Pole and South Pole. The rising temperature has led to deglaciation at rates of over $0.2 \% \mathrm{yr}^{-1}$ (Ye et al., 2017) and permafrost degradation (Wu et al., 2010) throughout the plateau, increasing the river runoff by $5.5 \%$ (Yao et al., 2007). Approximately $40 \%$ of the TP is considered permafrost and $56 \%$ seasonally frozen ground (Zou et al., 2017). Permafrost is vulnerable to climate change (Schuur et al., 2015), and it has been shown that climate warming may accelerate permafrostrelated creeping and sliding (Daanen et al., 2012). Glaciers and their retreat are very well documented on the TP, as they can be assessed using optical satellite data with high accuracy (e.g., Bolch et al., 2010). Permafrost features, such as rock glaciers or buried ice lenses, are harder to quantify using optical remote sensing due to their relatively slow motion and often smaller size than glaciers (Kääb, 2008). This has led to a severe lack of inventories documenting these permafrost features, despite their importance in water storage (Jones et al., 2019) and the vulnerability of rock glaciers to climate warming (Müller et al., 2016).

Permafrost-related displacement processes, such as rockslides and the creeping of rock glaciers, can be monitored through the collection of in situ surface (e.g., Böhme et al., 2016) and subsurface data (e.g., Kneisel et al., 2014) or with terrestrial remote sensing techniques like laser scanners (e.g., Bauer et al., 2003). These techniques are generally labor intensive, require access to the often remote study sites and provide only sparse spatial coverage. Satellite-based remote sensing does not require access to the study sites and provides large spatial coverage, making it a valuable tool for the study of permafrost-related displacements. The displacements vary from a few centimeters (heave and subsidence of the active layer) to decimeters or meters per year (creep of rock glaciers) and are therefore often too small to be studied with optical satellite techniques (Kääb, 2008). Cloud cover may inhibit the collection of continuous optical time series data (Joshi et al., 2016). However, satellites emitting microwaves, like the Sentinel-1 constellation launched by the ESA in 2014, make the continuous detection of these displacements possible through Interferometric Synthetic Aperture Radar (InSAR) techniques. InSAR analysis is an active remote sensing technique, which exploits phase changes of backscattered microwaves to determine relative surface displacements taking place between two or more acquisition dates (Osmanoğlu et al., 2016). Other studies have employed InSAR techniques to study permafrost-related processes on the TP (Li et al., 2015; Daout et al., 2017), in northwestern Bhutan (Dini et al., 2019), Norway (Eriksen et al. 2017), in Svalbard (Rouyet et al., 2019) and in Siberia (Antonova et al., 2018). Both seasonal processes, such as the heave and subsidence of freezing and thawing ground, and multiannual processes, like creep of periglacial landforms, have been studied. However, interpreting InSAR data can be challenging and of- ten a number of assumptions have to be made. InSAR results provide only motion towards the satellite or away from it, not absolute ground displacement. It is therefore very difficult to accurately assess ground motion, without making assumptions about its actual direction. Unlike optical satellites, which observe the Earth from a vertical line of sight (LOS), SAR satellites are side-looking and observe the Earth obliquely.

This paper presents the results of an analysis of ground movement in the permafrost-prone area of the eastern and southern shores of Nam Co based on 3- to 4-year time series of Sentinel-1 acquisitions. We identify the various surface processes driving surface displacement around Nam Co on the southern TP and evaluate their potential causes. It is vital to understand these displacement patterns and to compare our results to similar studies, as the TP has been shown to react heterogeneously to climate change (Song et al., 2014). To that end we developed multiple surface displacement models, analyzing geomorphological processes in the valleys and on the mountain slopes on both seasonal and multiannual scales.

\section{Study area}

Nam Co is the second largest lake of the TP (Zhou et al., 2013), with a catchment covering an area of $10789 \mathrm{~km}^{2}$, $2018 \mathrm{~km}^{2}$ of which is the lake's own surface area (Zhang et al., 2017). The proximity to Lhasa, its accessibility and the presence of the Nam Co Monitoring and Research Station for Multisphere Interactions CAS (NAMORS, Fig. 1) have made it a prime location to study the effects of climate change on the TP. The current lake level lies at $4726 \mathrm{~m}$ a.s.l. (Jiang et al., 2017), but it has featured a rising trend of approximately $0.3 \mathrm{~m} \mathrm{yr}^{-1}$ over the past decades (Kropáček et al., 2012; Lei et al., 2013). The eastern and southern borders of the catchment are defined by the Nyainqêntanglha mountain range with elevations of up to $7162 \mathrm{~m}$ a.s.l. The highest parts are glaciated (Bolch et al., 2010), while most other areas are considered to be in the periglacial zone (Keil et al., 2010; Li et al., 2014).

The climate at Nam Co is dominated by the Indian Monsoon in summer and the westerlies in winter (Yao et al., 2013). The former brings warm moist air from the south, providing 250 to $450 \mathrm{~mm}$ of rainfall from June to September and accounting for approximately $80 \%$ of the annual precipitation (NAMORS, 2018; location in Fig. 1a). The westerlies maintain semiarid to arid conditions during the rest of the year. The snow cover is relatively sparse in winter, due to low precipitation outside of the monsoon season. The vegetation consists primarily of alpine steppe ( $\mathrm{Li}, 2018)$, with high vegetation, such as shrubs and trees, being almost completely absent. The sparse snow cover and the lack of high vegetation make this region a prime study site for surface displacement related to periglacial processes using InSAR technology. Wang et al. (2017) used a combination of InSAR and optical satellite data to map rock glaciers in the north- 


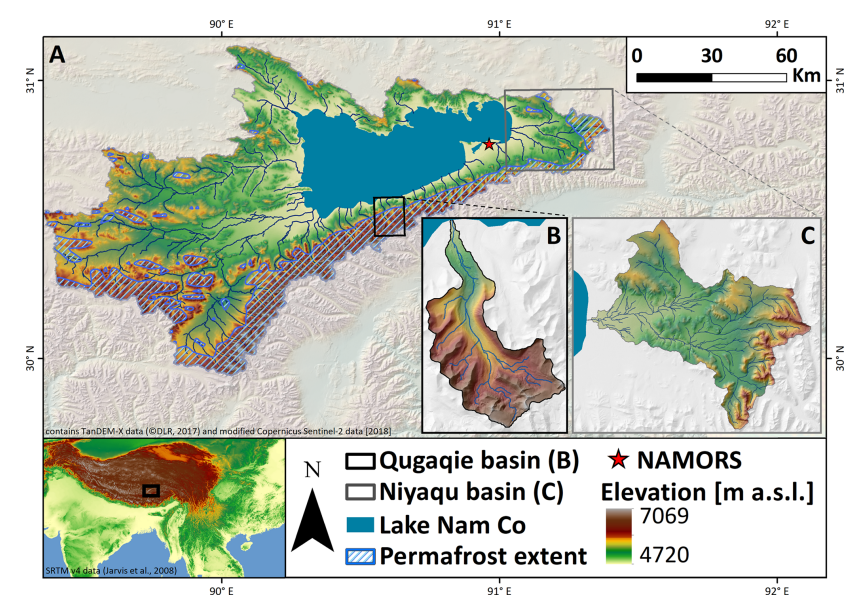

Figure 1. Overview map of the Nam Co catchment (a) including the locations of the NAMORS research station and the two main study areas: Qugaqie basin (b) and Niyaqu basin (c). Elevation data are based on SRTM v4 (Jarvis et al., 2008) and TanDEM-X 0.4" DEM (CDLR, 2017). Permafrost extent according to Zou et al. (2017) and lake extent based on the normalized difference water index (NDWI) of Sentinel-2 optical imagery (CCopernicus Sentinel data 2018, processed by ESA).

ern Tien Shan of China, where the winters are similarly dry. The risk of temporal decorrelation, i.e., the loss of data coverage due to considerable change of physical surface characteristics, is lower than in other regions where such processes may be studied, such as Norway (Eriksen et al., 2017) or the Sierra Nevada in the USA (Liu et al., 2013). These regions feature considerable snow cover during long periods of the year, making continuous temporal coverage of fast-moving structures, like rock glaciers, difficult. This is especially a problem for satellites with the shorter X-band $(2-4 \mathrm{~cm})$ or Cband $(4-8 \mathrm{~cm})$ wavelengths, like TerraSAR-X $(3.1 \mathrm{~cm})$ and Sentinel-1 $(5.6 \mathrm{~cm})$, as they are more susceptible to temporal decorrelation (Crosetto et al., 2016) compared to systems with a longer wavelength such as the L-band $(15-30 \mathrm{~cm})$.

The two areas of interest for this study are the Qugaqie basin $\left(58 \mathrm{~km}^{2}\right)$ within the western Nyainqêntanglha mountain range, south of Nam Co and the Niyaqu basin $\left(409 \mathrm{~km}^{2}\right)$ in the eastern Nyainqêntanglha mountain range, on the eastern shore of the lake (Fig. 1). These sub-catchments were chosen as they feature different levels of glacial impact and represent the predominant landscapes and their related surface processes at Nam Co. The Niyaqu basin represents the majority of Nam Co's catchment with extensive alpine steppe vegetation and wetlands surrounded by hills with little exposed bedrock in the lower regions. The global permafrost map of Zou et al. (2017) shows that permafrost is limited to the higher parts of the sub-catchment, in the eastern Nyainqêntanglha mountain range. The Qugaqie basin represents the periglacial landscape of the western Nyainqêntanglha mountain range. A total of $60 \%$ of its area is considered periglacial landforms (Li et al., 2014), some of which are still active in the higher parts of the catchment due to their potential ice content, such as rock glaciers. Rock glaciers are steadily creeping ice-rich debris on mountainous slopes associated with permafrost (Haeberli et al., 2006). Other landforms were shaped by fluvial, glaciofluvial, glacial and aeolian processes (Keil et al., 2010). The vegetation cover is similar to that of the Niyaqu basin but with more areas of exposed glacial valley fill and bedrock interspersed in between the vegetated areas. Both the valleys and the slopes are covered by unconsolidated debris, mostly coarse gravel and boulders, and some slopes in the higher parts are free of soil and vegetation. Steep topography and the presence of warming permafrost can be associated with rock slope instabilities, such as rockfalls and rockslides (Fischer et al., 2006), making them a likely occurrence throughout the Qugaqie basin and in the higher zones of the Niyaqu basin. The bedrock consists of sandstone and carbonates in the lower areas of the basins and granodiorite and metasedimentary rocks in the higher parts (Kapp et al., 2005; Yu et al., 2019). The main river is fed by hanging valleys, some containing glaciers, as well as the two main glaciers Zhadang and Genpu to the south. The glaciers cover $8.4 \%$ of the basin's surface area and account for $15 \%$ of its runoff in summer (Li et al., 2014). Two automated weather stations and a rain gauge were operated near the ablation zone of Zhadang Glacier between 2005 and 2010. Daily temperature averages range from approximately $-15^{\circ} \mathrm{C}$ in winter to $3^{\circ} \mathrm{C}$ in summer in the Qugaqie basin and -10 to $10^{\circ} \mathrm{C}$ in the Niyaqu basin (NAMORS, 2018; Zhang et al., 2013).

\section{Data}

We use Sentinel-1 Level-1 single-look complex data for all InSAR analysis, from both ascending and descending orbits from the interferometric wide-swath mode with a ground resolution of $20 \mathrm{~m}$ azimuth and $5 \mathrm{~m}$ in the range direction (ESA, 2012). We used a multi-looking factor of 4 in the range direction and 1 in the azimuth direction to achieve a ground resolution of $20 \mathrm{~m}$. Sentinel-1 observes the Earth's surface at an angle of 33 to $43^{\circ}$ from the vertical (Yagüe-Martínez et al., 2016). SAR satellites are generally right-looking, meaning the microwaves are emitted to the right of the satellite. Due to the polar orbit, this causes the microwaves to be emitted in a near-east direction while the satellite is ascending and in a near-west direction during descending data acquisitions. The high elevation of the TP brings both advantages and disadvantages to InSAR applications. Large altitude variations can be problematic due to artifacts caused by atmospheric delay (Li et al., 2012), while the lack of high and dense vegetation reduces the risk of decorrelation, which would otherwise lead to poor phase stability, so-called coherence.

Sentinel-1a has been acquiring data since October 2014 and Sentinel-1b since September 2016. We started our time 
Table 1. Sentinel-1 data used for the time series analysis of both study areas.

\begin{tabular}{lllrrr}
\hline $\begin{array}{l}\text { Area of } \\
\text { interest }\end{array}$ & Orbit & $\begin{array}{l}\text { Acquisition } \\
\text { period }\end{array}$ & $\begin{array}{r}\text { Acquisitions/ } \\
\text { interferograms }\end{array}$ & $\begin{array}{r}\text { Temporal } \\
\text { baselines }\end{array}$ & $\begin{array}{r}\text { Incidence } \\
\text { angle }\end{array}$ \\
\hline Niyaqu & ascending & 31 December 2014-22 December 2018 & $79 / 244$ & $12-60 \mathrm{~d}$ & $40-42^{\circ}$ \\
Niyaqu & descending & 14 December 2014-11 November 2018 & $72 / 227$ & $12-60 \mathrm{~d}$ & $39-41^{\circ}$ \\
Qugaqie & ascending & 5 June 2015-22 December 2018 & $74 / 278$ & $12-72 \mathrm{~d}$ & $36-37^{\circ}$ \\
Qugaqie & descending & 15 November 2015-29 December 2018 & $63 / 257$ & $12-96 \mathrm{~d}$ & $43^{\circ}$ \\
\hline
\end{tabular}

series analysis of the Qugaqie basin in May and November 2015 for ascending and descending acquisitions, respectively, due to low coherence in earlier acquisitions. Early data over the Niyaqu basin produce better interferograms; here we start our time series analysis in December 2014 already for both ascending and descending acquisitions. The latest acquisitions included in the analysis are from November and December 2018. Sentinel-1b data are not available for this region, except for a 3-month period at the end of 2016 in descending orbit. More detailed information about the number of acquisitions and interferograms is shown in Table 1. The temporal baselines of interferograms are 12 to $60 \mathrm{~d}$ for the Niyaqu basin and 12 to $96 \mathrm{~d}$ for the Qugaqie basin. We increased the temporal baseline for the Qugaqie basin to avoid a temporal data gap during the summer months of 2016 and 2017 caused by interferograms with low overall coherence. Decorrelation can occur where the surface displacement is greater than half the wavelength between two acquisitions (Crosetto et al., 2016). This applies to areas with LOS velocities $>17.0 \mathrm{~cm} \mathrm{yr}^{-1}$ in the Niyaqu basin and $10.6 \mathrm{~cm} \mathrm{yr}^{-1}$ in the Qugaqie basin. All topographic analysis and processing, including the removal of the topographic phase from the InSAR data, were conducted using the 0.4 arcsec, equal to $12 \mathrm{~m}$ at the Equator, resolution TanDEM-X DEM (ODLR, 2017). This new and truly global DEM was acquired in 2010 to 2015 using single-pass X-band SAR interferometry (Zink et al., 2014) and finally released by German Aerospace Agency in 2017. On the global scale the DEM features an absolute error at the $90 \%$ confidence level of $<2 \mathrm{~m}$ (Wessel et al., 2018). In steep terrain accuracy is ensured by multiple data takes in ascending and descending orbits with varying incidence angles to prevent radar shadows and overlay. In the Niyaqu basin, the number of acquisitions per pixel ranges from five to eight, with the majority representing average height estimates based on six acquisitions. Here, the mean $1 \sigma$ height error is $0.30 \mathrm{~m}$. In the steeper Qugaqie basin the number of acquisitions ranges from 8 to 12 , with the majority at nine acquisitions. Here, the mean of the $1 \sigma$ height error is $0.35 \mathrm{~m}$.

\section{Methods}

\subsection{ISBAS processing}

There are many different InSAR techniques capable of time series analysis to determine surface displacement over time. We chose a modified version of the small baseline subset (SBAS) method (Berardino et al., 2002), which we performed with the ENVI SARscape software (OSarmap SA, 2001-2019). The SBAS method generates interferograms between SAR acquisitions with a temporal baseline under a chosen threshold and stacks them to estimate displacement and velocity over a longer time period. Interferograms are a spatial representation of the phase difference of two SAR acquisitions and can be used to determine the relative surface displacement between them. The phase stability, so-called coherence, is often used to represent the quality of an interferogram and to determine which pixels will be processed further (Crosetto et al., 2016). The modified SBAS approach we employ, referred to as intermittent SBAS (ISBAS), produces an improved spatial coverage by allowing limited interpolation of temporal gaps for areas where the coherence is intermittently below the chosen threshold (Sowter et al., 2013; Batson et al., 2015). This reduces one of the downsides of the original SBAS algorithm, where partially vegetated areas can often not be processed, due to the poor coherence induced by vegetation. We chose a coherence threshold of 0.3 for our velocity models with an intermittent value of 0.75 , and therefore $75 \%$ of the interferograms need to produce a coherence of at least 0.3 to be considered during unwrapping. These parameters are similar to those used by Sowter et al. (2013) and Bateson et al. (2015) and produce an acceptable compromise of good spatial coverage, while excluding most unreliable data from the unwrapping process. We carefully analyzed all individual interferograms and excluded those with unwrapping errors and overall low coherence and therefore poor spatial coverage.

The topographic phase was removed from the interferograms with the TanDEM-X 0.4 arcsec resolution DEM (Wessel et al., 2018), and the orbital phase was removed by subtracting a constant simulated phase from our interferograms. We then estimated and subsequently subtracted a third-order polynomial function over flat stable areas to remove any remaining large-scale phase ramps. To reduce spatial trends connected to the small size of the Qugaqie basin, we pro- 
cessed a larger area which also includes the two neighboring catchments during the ISBAS workflow. Zhao et al. (2016) demonstrated that using a linear model to process regions with cyclical heave-subsidence mechanisms leads to an overestimation of the displacement signal. We could not confirm their findings in our study areas. We therefore decided to use a linear model for all processing, as the quadratic model produced almost identical results and the cubic model produced unreliable results with poor spatial coverage. We applied a short atmospheric high-pass filter of only $100 \mathrm{~d}$, to preserve the seasonal signal for our time series analysis, and a lowpass filter of $1200 \mathrm{~m}$.

After performing the ISBAS processing chain, flat areas within the Qugaqie basin retained a relatively strong spatial trend of up to 9 and $13 \mathrm{~mm} \mathrm{yr}^{-1}$ in ascending and descending datasets, respectively. This signal is likely connected to an atmospheric phase delay rather than actual surface displacement. We therefore performed a linear trend correction to remove this spatial trend from both ascending and descending datasets. The linear spatial trend was estimated through likely unmoving areas with a very low slope of $<5^{\circ}$ with at least $200 \mathrm{~m}$ distance to water bodies (based on NDWI of Sentinel-2 optical imagery, CCopernicus Sentinel data 2018, processed by ESA). After these corrections we performed a decomposition of ascending and descending datasets where we assume displacement in the north-south direction to be insignificant, to determine vertical and east-west displacements. We observe insignificant mean east-west velocities of -0.2 and $-0.9 \mathrm{~mm} \mathrm{yr}^{-1}$ with standard deviations of 2.2 and $2.4 \mathrm{~mm} \mathrm{yr}^{-1}$ in likely stable areas in the Niyaqu and Qugaqie basins, respectively.

\subsection{Selection of reference areas}

InSAR displacement products are spatially relative to the chosen reference areas. It is necessary to select at least one reference to perform the unwrapping process during the InSAR processing chain. Stable GNSS stations are preferred reference points but there are no permanent GNSS stations installed near the study areas. Therefore it is necessary to select the stable reference areas carefully to avoid introducing an erroneous trend signal into the surface displacement models. The parameters by which those stable reference areas were chosen are as follows.

1. The reference points must be at locations which are represented clearly in $100 \%$ of all interferograms generated during the SBAS processing chain, to ensure that the displacement of all interferograms can be correctly determined relative to those points.

2. Whenever possible we selected bedrock at high elevations far away from the valley floor. The annual heavesubsidence cycle, and the corresponding uplift and subsidence of the ground, is very strongly represented in the highly moisturized ground of the valley floor. Choos- ing reference points in this environment would remove this annual ground oscillation from the dataset in the valley floor and create an artificial and opposite oscillation pattern in other areas. Bedrock has a much smaller porosity than loose sediment or soil and is therefore less prone to oscillations forced by freezing and thawing of pore fluid. Stable bedrock is associated with a high coherence throughout the year, due to its relatively stable backscatter characteristics.

3. The chosen reference points must be stable during the entire period of observation, as moving reference points would shift the entire velocity model. We compared the results of different reference points in areas where we expect little motion and discarded those that caused a shift. As reference areas we chose regions with a low slope, good coherence and no obvious deformation structures, and we assume them to be stable in time.

Despite our careful selection of reference points, we cannot be certain that those areas are in fact stable throughout the entire data acquisition period. We therefore chose to use multiple reference points instead of a single point to produce the surface velocity models. This prevents a single, potentially poorly selected, reference point from invalidating the entire dataset by introducing either a multiannual velocity shift or seasonal displacement signal. The areas of partially exposed bedrock and the mountainous terrain of the Qugaqie basin made the selection of reference points easier compared to the Niyaqu basin, where exposed bedrock is rare. Selecting only points positioned at these optimal locations left us with none near the center of the basins or the lakeshore. This caused velocity shifts along the LOS on a millimeter scale in presumably stable flat areas, if they were far away from the reference points. We therefore increased the number of reference points to 90 and 51 in the Qugaqie basin and 92 and 61 in the Niyaqu basin for ascending and descending acquisitions, respectively. Maps showing their locations are included in the Supplement. The number of reference areas varies between ascending and descending acquisitions, due to differences in coherence, but we chose the same reference areas whenever possible.

\subsection{Surface displacement models}

In total we produced three different types of surface displacement models (Table 2) for the Niyaqu and Qugaqie basins: the linear velocity model (LVM), the heave-subsidence model (HSM) and the seasonal slope process model (SSM). The LVM portrays the mean surface velocity from 2015 to 2018 and does not portray seasonal variations. It describes both valleys and slopes, but we make the assumption that displacements are predominantly vertical in areas with slopes $<10^{\circ}$ and orientated in a downslope direction in steeper areas. The HSM models the heave-subsidence cycle caused by freezing of the active layer in autumn followed by sub- 
Table 2. Overview of the three surface displacement models with information regarding their purpose, displacement patterns and their connections to geomorphological und geological parameters.

\begin{tabular}{|c|c|c|c|}
\hline Model type & LVM (linear velocity model) & $\begin{array}{l}\text { HSM (heave-subsidence } \\
\text { model) }\end{array}$ & $\begin{array}{l}\text { SSM (seasonal slope process } \\
\text { model) }\end{array}$ \\
\hline Purpose & $\begin{array}{l}\text { Multiannual subsidence, sediment } \\
\text { accumulation and permafrost } \\
\text { creep }\end{array}$ & $\begin{array}{l}\text { Seasonal heave-subsidence } \\
\text { cycle due to freezing and } \\
\text { thawing of the active layer }\end{array}$ & $\begin{array}{l}\text { Seasonally accelerating slope } \\
\text { processes }\end{array}$ \\
\hline Displacement type & $\begin{array}{l}\text { Multiannual linear velocity along } \\
\text { the slope or vertical }\end{array}$ & $\begin{array}{l}\text { Seasonal vertical } \\
\text { displacement }\end{array}$ & $\begin{array}{l}\text { Seasonal displacement along } \\
\text { the slope }\end{array}$ \\
\hline Slope & $\begin{array}{l}<10^{\circ}: \text { vertical velocity } \\
>10^{\circ}: \text { along slope velocity }\end{array}$ & $<10^{\circ}$ & $>10^{\circ}$ \\
\hline Material & Soil, regolith, till, debris and ice & Mainly soil & Regolith, debris and ice \\
\hline $\begin{array}{l}\text { Related geomorpholog- } \\
\text { ical processes }\end{array}$ & $\begin{array}{l}\text { Long-term subsidence, sediment } \\
\text { accumulation and permafrost } \\
\text { creep }\end{array}$ & $\begin{array}{l}\text { Heave-subsidence cycles } \\
\text { connected to cryoturbation }\end{array}$ & $\begin{array}{l}\text { Solifluction, gelifluction and } \\
\text { rock slope instability on } \\
\text { seasonally frozen slopes }\end{array}$ \\
\hline Associated landform & $\begin{array}{l}\text { Rock glaciers, protalus ramparts } \\
\text { and moraines }\end{array}$ & Valley bottom terrain & $\begin{array}{l}\text { Debris mantle slopes, solifluc- } \\
\text { tion lobes and rockslides }\end{array}$ \\
\hline
\end{tabular}

sequent thawing of the active layer in spring. It covers only areas with slopes $<10^{\circ}$, shows only seasonal displacement and assumes that all displacement is vertical. The SSM focuses on slopes where sliding is accelerated from spring to autumn, to be differentiated from slopes in the LVM where sliding takes place throughout the year at a near-linear rate. It only covers slopes $>10^{\circ}$ and assumes that all displacement is orientated in a downslope direction.

\subsubsection{Linear velocity model (LVM)}

This model portrays the mean annual surface velocity, with different methods applied to regions with a slope $>10^{\circ}$ and with a slope $<10^{\circ}$. Seasonal displacement trends are not present in this model, as we address those in the separate models HSM and SSM. The original ISBAS processing chain (Sect. 4.1) is the same but we applied different methods to project the LOS results into a more meaningful direction. For areas with a slope $<10^{\circ}$, we assumed that displacement would occur mainly in the vertical direction, as the slope would be too small to facilitate significant sliding or creep in most cases. Matsuoka (2001) shows that while solifluction has been documented on slopes as low as $2^{\circ}$, most affected areas in midlatitude to tropical mountains (including the TP) feature slopes $>10^{\circ}$. To determine the vertical velocity, we performed a decomposition of ascending and descending time series data. For this process we assume the north-south component of the surface displacement to be zero, which allows us to determine the vertical and eastwest components (Eriksen et al., 2017). The vertical component represents our expected surface velocity for flat areas, while the east-west component can be used to assess the error range of the velocity model.
The decomposition method works well for flat regions and slopes with an east or west aspect but does not produce useful data for slopes with a north or south aspect. The Sentinel1 SAR satellite constellation is quite sensitive to both eastwest and vertical surface displacement, but very insensitive to displacement with a strong north or south component. This is problematic when studying displacements with a large horizontal component, as the velocity of surfaces moving in a northern or southern direction will be either severely underestimated or completely overlooked. We therefore employed a different method for slopes. Areas with a slope $>10^{\circ}$ were projected in the direction of the steepest slope, as most surface displacement is assumed to be caused by sliding processes transporting material parallel to the slope. We made an exception for areas with an east-west velocity $>10 \mathrm{~mm} \mathrm{yr}^{-1}$, as our study areas feature a periglacial setting with landforms such as rock glaciers, which move in a downslope direction and may extend into flatter areas. Those areas were projected in a downslope direction, even on slopes $<10^{\circ}$. This approach (Notti et al., 2014) originated from landslide studies to produce a more accurate result for a process where the direction of the moving structure is either known or can be assumed with reasonable certainty.

To estimate the downslope velocity, we calculate a downslope coefficient, with values between 0.2 and 1 , and divide the LOS velocity by this coefficient to determine the downslope velocity. Maps of the spatial distribution of this coefficient are included in the Supplement. We used a smoothed version (90 $\mathrm{m} \times 90 \mathrm{~m}$ moving mean) of the TanDEM-X DEM to determine the motion direction, as we assume that structures such as rock glaciers and landslides move a larger amount of sediment in a similar direction. Small-scale variations in the aspect or slope have a strong impact on the 
downslope coefficient and would create outliers in the slope projection in areas with high surface roughness. It is important to note that by projecting LOS velocities along the steepest slope, we not only assume the direction vector, but we also simplify the mechanics to that of a planar slide. In doing so we assume that neither rotational nor compressing processes are involved. This is an obviously unrealistic but necessary simplification, which leads to on overestimation of the downslope velocity. The error range of the slope projection can be up to 5 times higher for areas with a very strong downslope coefficient than the range of $\pm 2.4 \mathrm{~mm}$ we determined over flat ground.

\subsubsection{Heave-subsidence model (HSM)}

Prior to analyzing the heave-subsidence amplitude, we projected the LOS displacements from both ascending and descending datasets to vertical displacements. We then removed the linear multiannual trend from the datasets to isolate the seasonal signal. Sum-of-sine functions were estimated for each individual time series. For the amplitude estimation in the Qugaqie basin we used a function with two sine terms and for the Niyaqu basin a function with three terms. We identified the sine term representing the seasonal signal and discarded the other terms. We calculated the mean values and the standard deviation of the amplitude, shift and period of the sine curve during the three to four seasonal cycles. We use the standard deviation of the amplitude and the shift as a measure of their error ranges. We also calculated the explained variation $\left(R^{2}\right)$, which represents the proportion of variation in the time series explained by the sine curve regression. To qualify for further analysis, a time series must display a heave-subsidence amplitude larger than $3 \mathrm{~mm}$, with an $R^{2}>0.5$ and a period of 350 to $380 \mathrm{~d}$. The main results of the HSM are the mean amplitude of the heave-subsidence cycle and the day of maximum subsidence (DMS). The DMS describes the mean day on which the sine function reaches its minimum. This represents the day on which the soil has subsided to its minimum level due to thawing before beginning to heave again due to freezing. The final HSM contains both ascending and descending data. In areas where they overlap we show the mean value of the two. Slopes $>10^{\circ}$ were excluded from the HSM as these areas are likely to display mainly gravity-driven displacement with a downslope direction and not only vertical heave-subsidence cycles. The seasonal displacement of slopes is covered by the SSM, and their multiannual velocity is shown in the LVM instead.

\subsubsection{Seasonal slope process model (SSM)}

The average seasonal velocities represent the median summer and median winter velocities over the entire time series. We divided the median summer velocity by the median winter velocity to produce the seasonal sliding coefficient, which represents how fast a surface is moving in summer compared to winter. Our SSM features a precision (1 sigma) of around $2.4 \mathrm{~mm} \mathrm{yr}^{-1}$. Time series with median seasonal velocities $<2 \mathrm{~mm} \mathrm{yr}^{-1}$ were set to $2 \mathrm{~mm} \mathrm{yr}^{-1}$, to avoid artificially large values when calculating the seasonal sliding coefficient with median seasonal velocities close to 0 . This affects $18.1 \%$ of slopes in the Niyaqu basin and $4.3 \%$ of slopes in the Qugaqie basin. The higher value in the Niyaqu basin is due to the lower overall velocity of slopes in that region and the reduced spatial coverage due to lower coherence in the higher zone where larger velocities occur. A seasonal sliding coefficient of 1.5 represents a $50 \%$ increased summer velocity compared to the winter velocity. We chose this threshold of 1.5 to differentiate between seasonally accelerated slopes and slopes with relatively linear velocity.

\section{Results}

\subsection{Linear surface velocity derived from LVM}

Solifluction may occur on slopes as low as $2^{\circ}$ but mostly affects areas with a slope $>10^{\circ}$ in midlatitude to tropical mountain areas (Matsuoka, 2001). This is corroborated by the east-west velocity produced by our decomposition of ascending and descending data. For the slopes of 0-5, 5-10 and $10-15^{\circ}$ we observe mean east-west velocities of -0.1 , -0.6 and $-0.6 \mathrm{~mm} \mathrm{yr}^{-1}$ at standard deviations of 3.0, 2.9 and $5.0 \mathrm{~mm} \mathrm{yr}^{-1}$, respectively. The jump in standard deviation from $5-10$ to $10-15^{\circ}$ from 2.9 to $5.0 \mathrm{~mm} \mathrm{yr}^{-1}$ suggests that we observe considerably more horizontal displacement in the latter group. This makes the $10^{\circ}$ mark a good threshold between the vertical and the downslope projections. For areas with a slope $>10^{\circ}$ we assumed that the displacement would occur along the steepest slope, driven by gravitational pull (Haeberli et al., 2006). Unconsolidated material and the lack of deep-rooted vegetation in the area (Li et al., 2014) facilitate downslope motion.

Spatial data gaps in our InSAR models are caused by layover and shadow effects in mountainous regions or where the coherence was lost due to streams, vegetation, rockfalls and glaciers. These data gaps make up $34.7 \%$ in flat and $31.4 \%$ in steep terrain within the Qugaqie basin and $30.5 \%$ and $36.0 \%$ in the Niyaqu basin. The decomposition of ascending and descending datasets of areas with flat terrain (slope $<10^{\circ}$ ) shows that both basins have relatively stable flat terrain on a multiannual scale. A total of $53.3 \%$ of flat areas in the Qugaqie basin and $64.4 \%$ in the Niyaqu basin fall within the $\pm 5 \mathrm{~mm} \mathrm{yr}^{-1}$ velocity group in both vertical and east-west directions. We consider these areas to be stable. In the Qugaqie basin, 3.3\% of flat areas experience uplift, most of which are near the main stream, while $2.8 \%$ of flat areas are subsiding. In the Niyaqu basin, $0.2 \%$ of flat areas experience uplift and $2.7 \%$ experience subsidence (Fig. 2). The remaining flat areas, $5.8 \%$ in the Qugaqie basin and $2.1 \%$ in the Niyaqu basin, experience minor horizontal motion. 


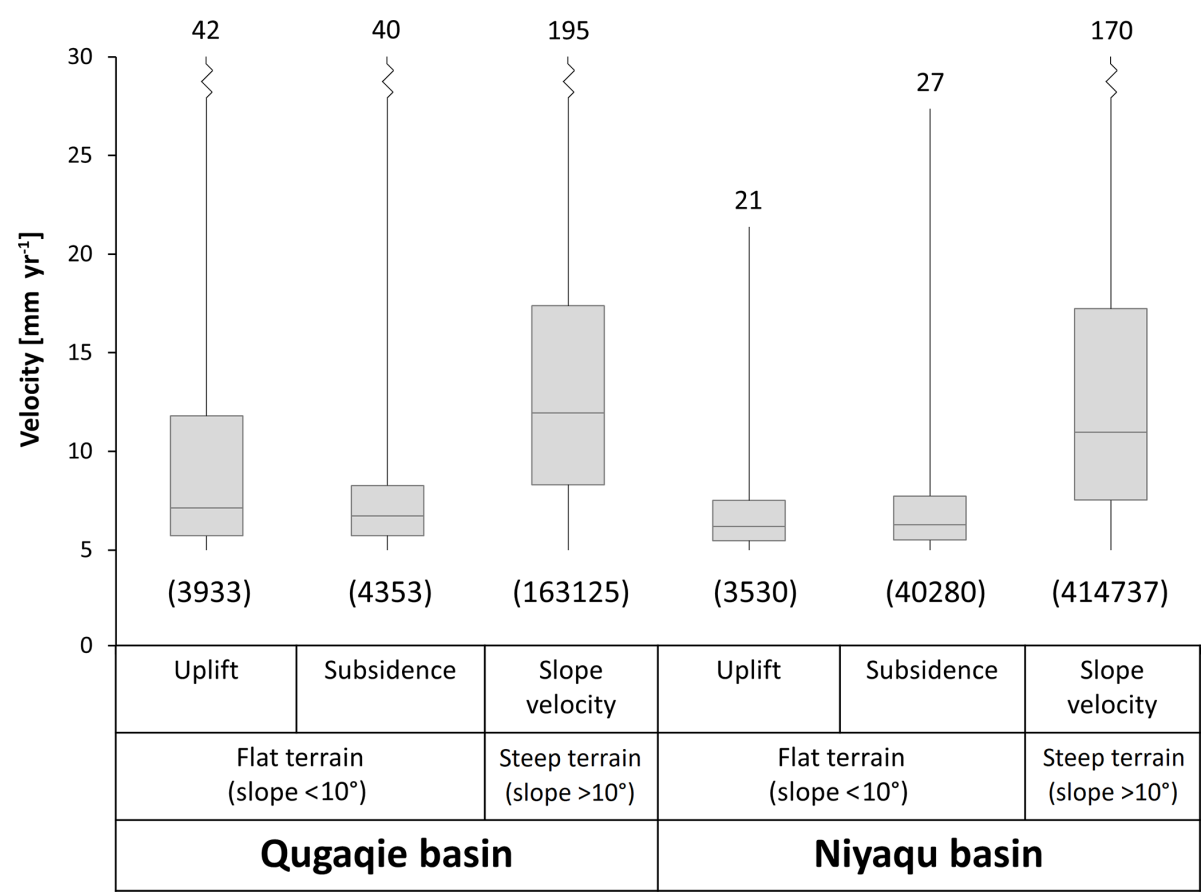

Figure 2. Distribution of the mean velocity results of the LVM for unstable flat and steep terrain in both study areas. All surface motion in flat areas (slope $<10^{\circ}$ ) was projected into the vertical direction (uplift and subsidence), and motion in steeper areas was projected along the direction of the slope. The maximum values are shown above the respective boxplots and the number of data points included in each plot is shown in parentheses below them. Areas with velocities $<5 \mathrm{~mm} \mathrm{yr}^{-1}$ are considered stable and are not shown here.

Table 3. Summary of the spatial data coverage of the LVM in the study areas. The values represent the percentages compared to all flat or steep terrain in the respective study area. Incoherent areas display a mean coherence of $<0.3$. Stable areas are characterized by multiannual velocities $<5 \mathrm{~mm} \mathrm{yr}^{-1}$ in all directions. Unstable flat areas move at $>5 \mathrm{~mm} \mathrm{yr}^{-1}$ and are divided into uplift, subsidence and horizontal motion (uplift/subsidence/horizontal). Steep unstable areas move at $>5 \mathrm{~mm} \mathrm{yr}^{-1}$ downslope and very unstable terrain moves at $>30 \mathrm{~mm} \mathrm{yr}^{-1}$.

\begin{tabular}{llrrrr}
\hline & Terrain & Incoherent & Stable & Unstable & Very unstable \\
\hline Qugaqie basin & flat $\left(<10^{\circ}\right)$ & 34.7 & 53.3 & $3.3 / 2.8 / 5.8$ & 0.1 \\
& steep $\left(>10^{\circ}\right)$ & 31.4 & 20.9 & 44.9 & 2.8 \\
\hline Niyaqu basin & flat $\left(<10^{\circ}\right)$ & 30.5 & 64.4 & $0.2 / 2.7 / 2.1$ & 0.0 \\
& steep $\left(>10^{\circ}\right)$ & 36.0 & 21.1 & 39.7 & 3.1 \\
\hline
\end{tabular}

Steep terrain is considerably more unstable in both study areas. In the Qugaqie basin only $20.9 \%$ of areas in steep terrain are stable, with $2.8 \%$ being very unstable with velocities $>30 \mathrm{~mm} \mathrm{yr}^{-1}$. In the Niyaqu basin $21.1 \%$ of areas in steep terrain are stable and $3.1 \%$ are very unstable. A summary of the spatial data coverage is shown in Table 3. A distribution of the absolute surface velocity results in different regions is shown in Fig. 3.

The coherence in both basins is much reduced in valley bottoms. Streams and other water bodies also affecting the soil moisture status of the neighboring land surfaces cause large changes in microwave backscatter properties depending on the season. More extensive vegetation near the valley bottom further reduces the coherence. The coherence is especially low in valley bottoms during the spring and the summer monsoon period, when the ground thaws, the surface is inundated by rainwater or runoff, and biomass production increases. This causes an overall drop in spatial data coverage in valley bottoms, as many resolution cells exhibit coherence values below the threshold. Coherence maps of ascending and descending orbit of both study sites are included in the Supplement.

\subsection{Heave-subsidence cycle derived from HSM}

The seasonal vertical oscillation of the ground due to freezing and thawing of the soil is strongest in the valley bottom, especially near streams, lakes, ponds and, in the case of the Qugaqie basin, glaciers (Fig. 5a, b). In these areas the amplitude of this oscillation can reach up to $19 \mathrm{~mm}$ in 

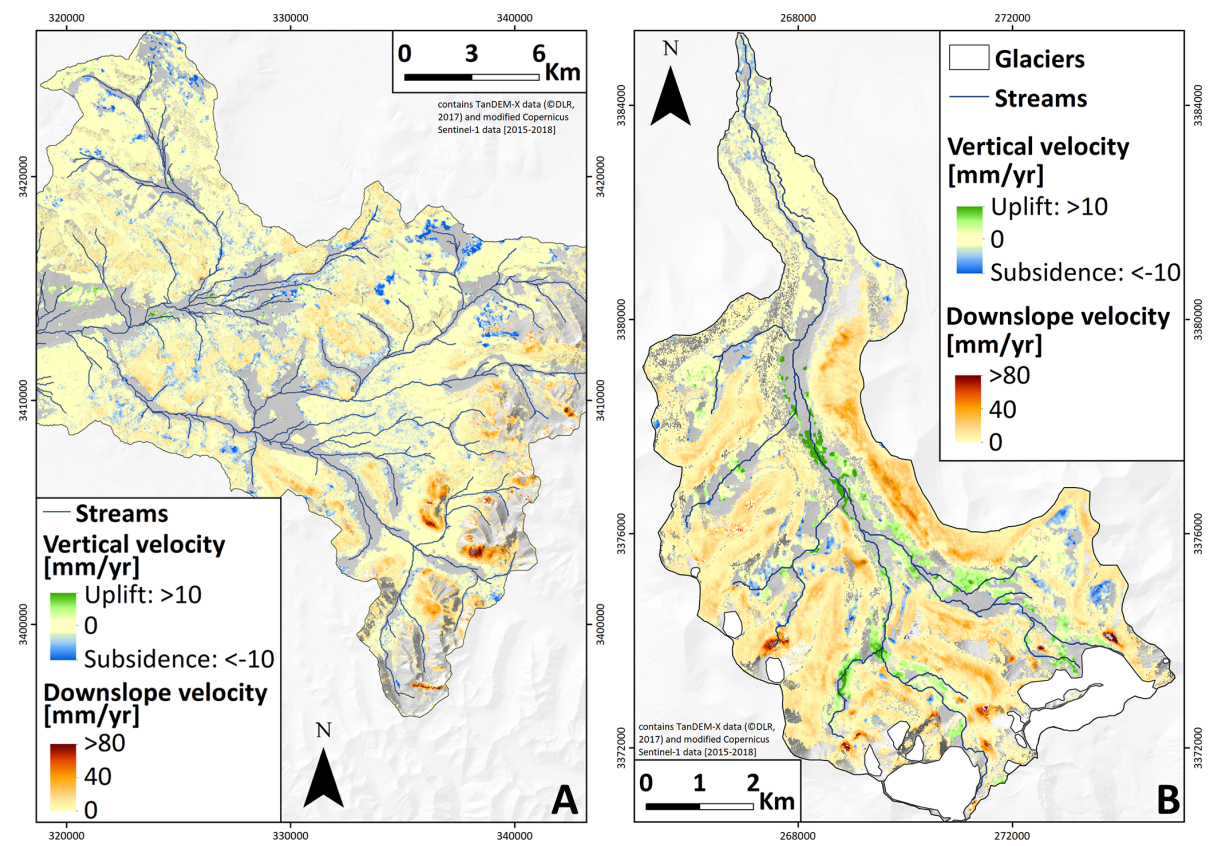

Figure 3. LVM of the Niyaqu (a) and Qugaqie (b) basins based on Sentinel-1 data (@Copernicus 2015-2018) over TanDEM-X DEM (ODLR, 2017). Flat terrain with a slope $<10^{\circ}$ shows vertical velocity, and steeper terrain shows the surface velocity projected along the steepest slope. Maps showing the spatial distribution of flat and steep terrain are included in the Supplement.

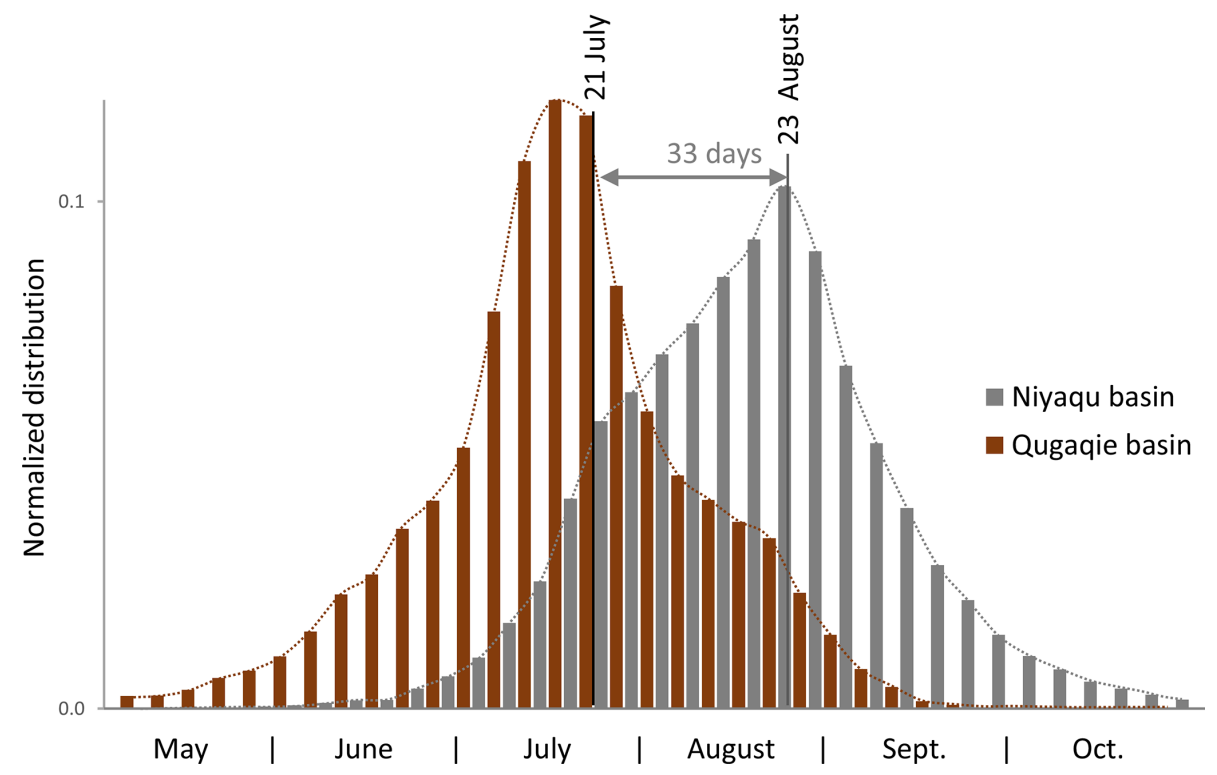

Figure 4. Normalized distribution of the thaw-induced day of maximum subsidence (DMS) in the Niyaqu basin (grey) with a median value on 24 August and the Qugaqie basin (brown) with a median value on 21 July. The lag time of $33 \mathrm{~d}$ between the median value of the Niyaqu basin and the day of the mean maximum air temperature on 21 July (NAMORS, 2018) is also shown. The median DMS of the Qugaqie basin occurs on 19 July, resulting in no clear lag time.

the Qugaqie basin or even $27 \mathrm{~mm}$ in the Niyaqu basin. The median amplitude error is $1.3 \mathrm{~mm}$ in the Niyaqu basin and $1.1 \mathrm{~mm}$ in the Qugaqie basin. The day of maximum subsidence (DMS) is the day in summer during which the soil has subsided to its minimum level before beginning to heave again in autumn (Fig. 5c, d). In the Qugaqie basin the median DMS is on 19 July and in the Niyaqu basin it is on $23 \mathrm{Au}-$ gust (Fig. 4). Most data points with heave-subsidence amplitudes of $<7 \mathrm{~mm}$ reach their DMS in July to August in the Niyaqu basin and May to July in the Qugaqie basin, while 

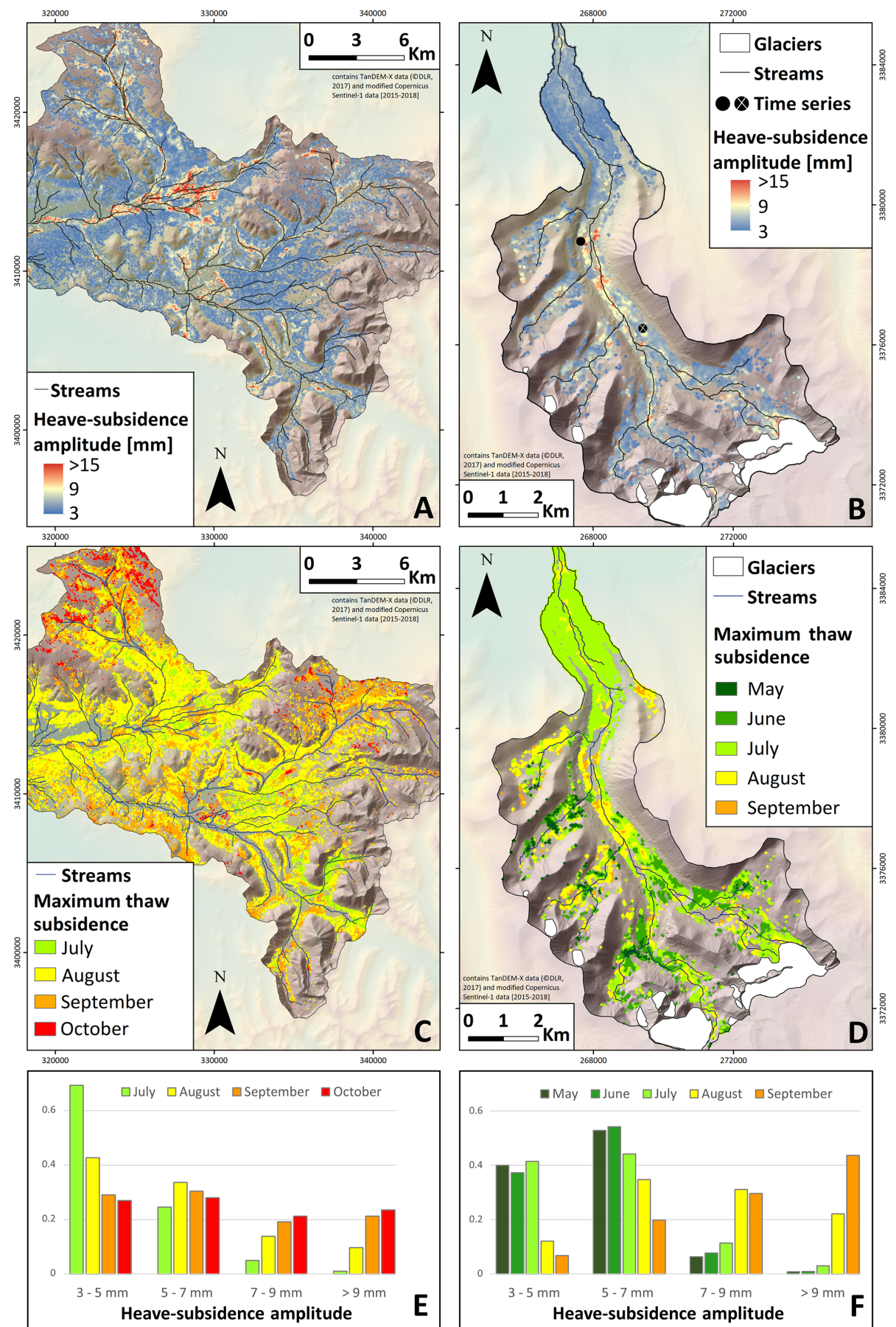

Figure 5. Parameters of the HSM (modified Copernicus Sentinel-1 data, 2015-2018) over TanDEM-X DEM (@DLR, 2017). Spatial variations in the mean amplitude $(\mathbf{a}, \mathbf{b})$ and the day of maximum subsidence (c, d) of the HSM within the Niyaqu and Qugaqie basins. The locations of the time series of Fig. 6a are displayed as black dots. (e, f) Normalized distribution of the months in which the heave-subsidence cycle reaches its maximum subsidence split up into four groups according to their amplitude for the Niyaqu and Qugaqie basins.

areas with larger amplitudes tend to reach theirs in September to October (Fig. 5e, f). The median shift error of the sine function modeling the heave-subsidence cycle is $33 \mathrm{~d}$ in the Niyaqu basin and $27 \mathrm{~d}$ in the Qugaqie basin. We compared the DMS results of ascending and descending datasets and noticed that in both basins the mean DMS of the descending dataset occurs earlier. In the Niyaqu basin the difference between ascending and descending DMS is $27 \mathrm{~d}$ and in the Qugaqie basin it is $10 \mathrm{~d}$. Maps showing the spatial distribution of this disparity are included in the Supplement. 
The freezing and thawing of soil follows the Stefan equation (Riseborough et al., 2008), and there is a significant lag time between the day of maximum air temperature and the DMS. This lag time has been studied with InSAR remote sensing techniques on both the northern and the southern TP (Li et al., 2015; Daout et al., 2017). According to the weather data from the NAMORS research station, the air temperature has a mean peak on 21 July from 2010 to 2017. Data from the weather station at the Zhadang glacier (Zhang et al., 2013) show this mean peak on 27 July for 2010 to 2011 (19 July for the same period at NAMORS). NAMORS research station is close to the Niyaqu basin but about $50 \mathrm{~km}$ distant from the Qugaqie basin and at lower altitude. The Zhadang glacier and its weather station are located within the Qugaqie basin. Due to the very short acquisition period of only 2 years for the Zhadang weather station, we chose the 8-year dataset of NAMORS for both study areas. This produces a lag time of approximately $33 \mathrm{~d}$ for the Niyaqu basin (Fig. 4, grey), while in the Qugaqie basin the median DMS occurs on 19 July, $2 \mathrm{~d}$ before the maximum air temperature on 21 July, resulting in no clear lag time (Fig. 4, brown).

\subsection{Seasonally accelerating slopes derived from SSM}

We identified two distinct seasons, the wet monsoon season in summer and the dry winter season, which have a clear impact on the displacement data. The former season causes accelerated ground sliding on many slopes, while the latter slows most sliding processes (Fig. 6c). We refer to this seasonally accelerated sliding as freeze-thaw-driven but it is possible that the water input during the monsoon period, which coincides with the highest annual air temperatures, amplifies this process. In the Niyaqu basin the accelerated displacement pattern of the summer period lasts from May to September and in the Qugaqie basin from June to October. The slower winter displacement patterns last from November to March and from December to April. We compared the median summer velocities to the median winter velocities of each time series over the entire study period. Most soil- or debris-covered slopes in both basins display accelerated sliding rates of $100 \%$ to $300 \%$ towards the end of the summer monsoon. They reach downslope velocities of mostly 50 to $150 \mathrm{~mm} \mathrm{yr}^{-1}$ during that time. The lower areas of most slopes appear to move at a linear rate. This marks the interface between the heave-subsidence cycle of the valley bottoms and the seasonally accelerated sliding on the slopes. These two seasonal displacement processes (Fig. 6a, c) are both present in those interface areas and often interfere with each other in such a manner that they appear to move linearly in the SSM.

In the Qugaqie basin and to a lesser extent in the Niyaqu basin, we observe that some of the fastest-moving structures creep at a linear rate, as opposed to the strong seasonality of most slopes. They do not display a clear acceleration in summer, and their multiannual velocity is generally between
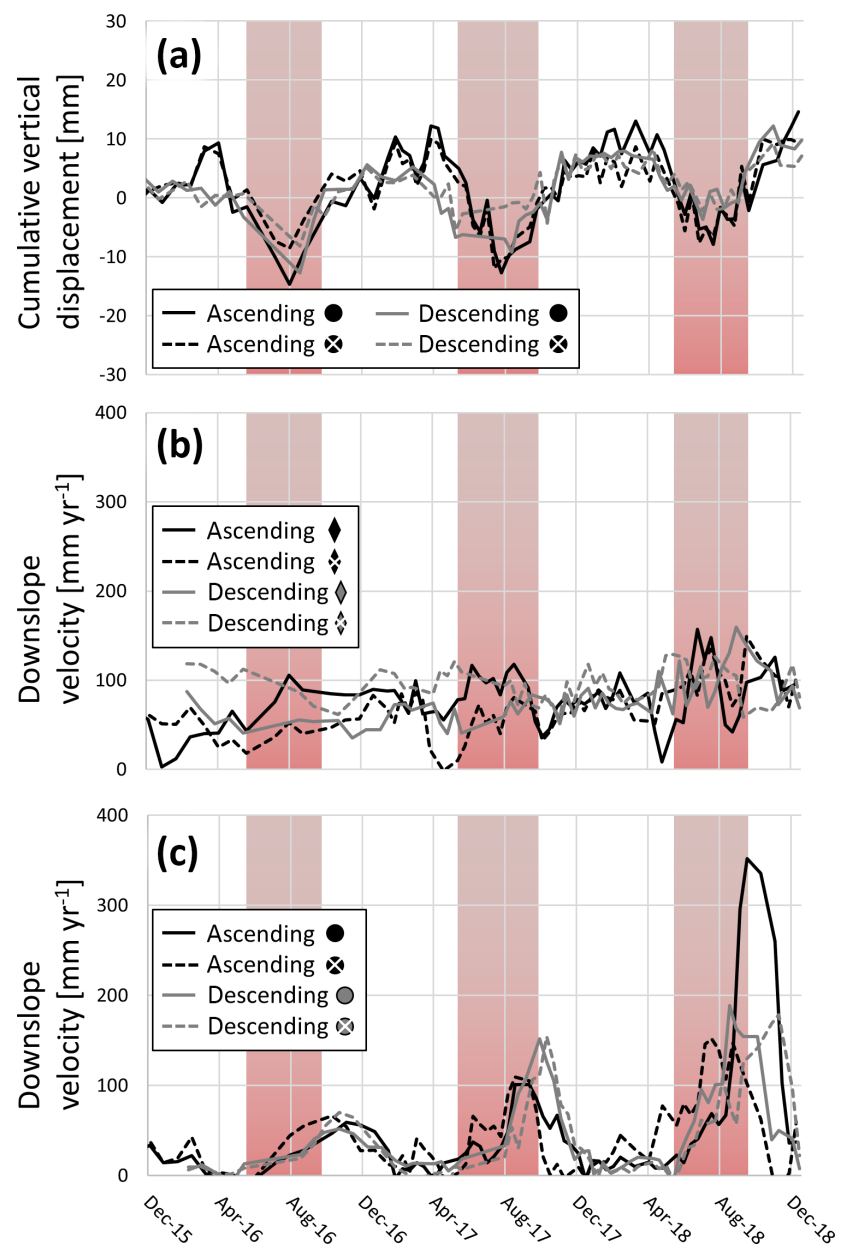

Figure 6. Surface displacement time series of both ascending (black, dashed black) and descending (grey, dashed grey) data of various areas throughout the Qugaqie basin highlighting the three seasonal patterns. June to September are shown with a red background as they display the strongest monsoon activity and air temperatures $>0{ }^{\circ} \mathrm{C}$ (Zhang et al., 2013). (a) Cumulative vertical displacement showing the seasonal heave-subsidence cycle of the HSM at two locations near the stream of the main valley (black dots in Fig. 5b). (b) Downslope velocity time series of the four gravitydriven landforms (rhombi in Fig. 7a) with relatively constant velocities (blue areas in Fig. 7a). (c) Freeze-thaw-driven displacement patterns on four slopes (dots in Fig. 7a) with accelerated displacements in summer and comparatively minor displacements in winter (red areas in Fig. 7a). Panels (b) and (c) display moving average values of the closest four values in time.

30 and $180 \mathrm{~mm} \mathrm{yr}^{-1}$ (Fig. 6b). We identified some of these landforms as rock glaciers or protalus ramparts from optical satellite imagery, field observations and topographic analysis. The motion of these permafrost-related landforms is driven by an ice matrix in between unconsolidated debris material (Haeberli et al., 2006). Rock glaciers and protalus ramparts represent $36 \%$ of the linearly fast-moving landforms in the Qugaqie basin and include the largest and the fastest land- 

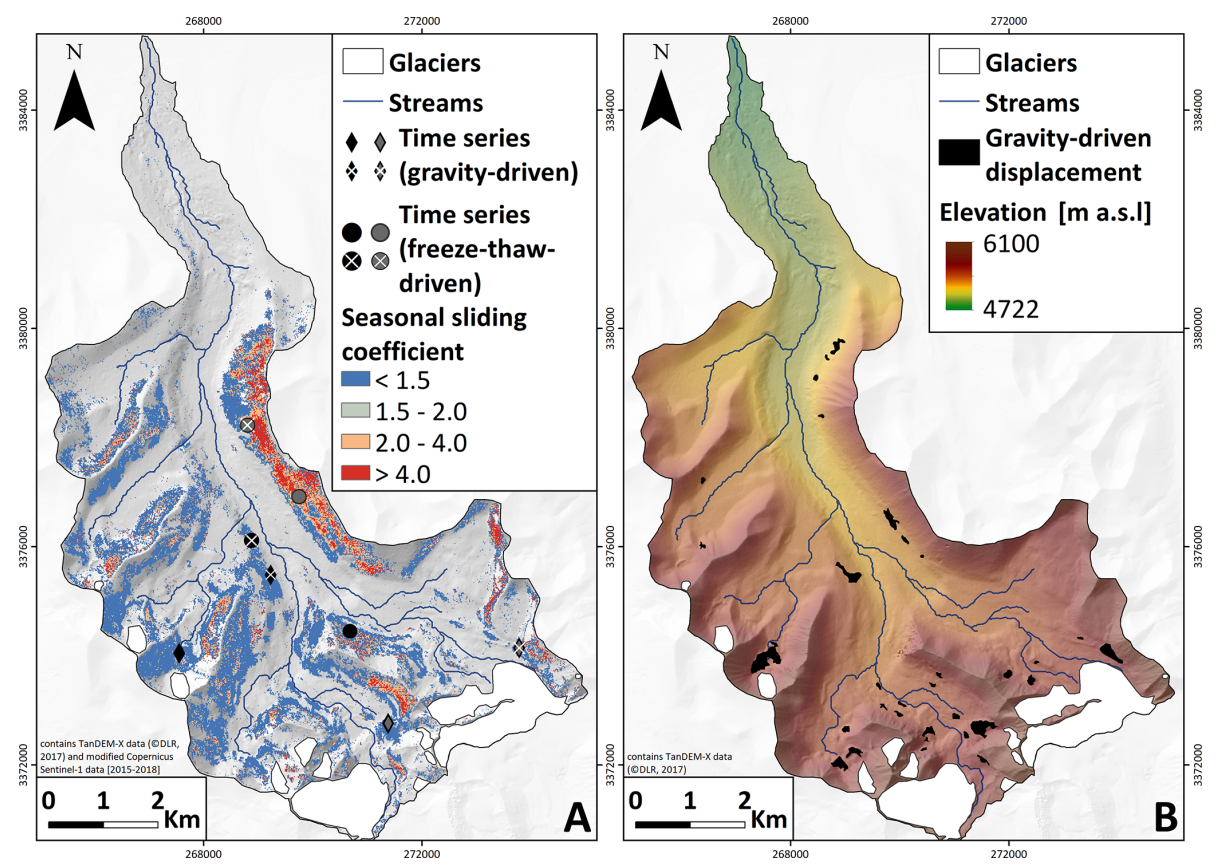

Figure 7. (a) SSM of the Qugaqie basin displaying the spatial distribution of slopes with accelerated surface velocity in summer compared to winter. A seasonal sliding coefficient of 1.5 represents a $50 \%$ increase in the velocity in summer. Only areas with a slope $>10^{\circ}$ and a slope velocity $>10 \mathrm{~mm} \mathrm{yr}^{-1}$ are shown. The locations of the time series in Fig. 6b, c are shown as rhombi/dots. (b) Spatial distribution of clusters where we assume displacement to be gravity-driven. These clusters display slope velocities $>50 \mathrm{~mm} \mathrm{yr}^{-1}$ and a seasonal sliding coefficient $<1.5$.

forms with this displacement pattern. Other landforms with this displacement pattern are rock slope instabilities (24\%) and frozen moraines (39\%). Example pictures of those three landform types are included in the Supplement. We focus our analysis of slope displacements on the Qugaqie basin, due to the considerably better overall coherence and therefore spatial coverage of slopes in the periglacial zone. The maps equivalent to Fig. 7 for the Niyaqu basin characterized by poor coherence in the periglacial zone can be found in the Supplement.

\section{Discussion}

We created three different models to study both seasonal and multiannual surface displacements and their driving processes in steep and flat terrain at Nam Co. We discuss the multiannual displacements of the LVM and the seasonal displacements of the HSM in flat terrain in Sect. 6.1 and 6.2, respectively. Multiannual displacements of the LVM and seasonal displacements of the SSM in steep terrain are discussed in Sect. 6.3 and 6.4, respectively.

For both our seasonal and our multiannual surface displacement models we distinguish between flat terrain with slopes $<10^{\circ}$ where we assume all displacement to be mainly vertical and steep terrain with slopes $>10^{\circ}$ where we assume displacement to occur in a downslope direction. We chose this threshold based on the decomposition of ascending and descending results, which shows a considerable increase in horizontal velocities on slopes $>10^{\circ}$ compared to flatter areas. While this simplification is necessary and mostly accurate for our study areas, it leads to inaccuracies in particular in areas with slopes of 5 to $15^{\circ}$ where displacements can occur in both vertical and downslope directions.

\subsection{Multiannual displacements in flat terrain}

Flat terrain throughout both basins can be considered relatively stable with mean vertical and east-west velocities within $\pm 5 \mathrm{~mm} \mathrm{yr}^{-1}$. Some areas in valley bottoms show uplift rates of up to $40 \mathrm{~mm} \mathrm{yr}^{-1}$ (Qugaqie basin, Fig. 3b) and $21 \mathrm{~mm} \mathrm{yr}^{-1}$ (Niyaqu basin, Fig. 3a). A possible explanation is that seasonal variations in the soil moisture content were misidentified as surface displacement. The meltwater and high monsoon precipitation increases the soil moisture in summer, which can lead to a false interpretation of surface displacement of $10 \%$ to $20 \%$ (Zwieback et al., 2017). In our case this would represent 5 to $10 \mathrm{~mm}$ per monsoon season for a total of 15 to $30 \mathrm{~mm}$. This is corroborated by the large amplitude of the heave-subsidence model in the same areas, which is associated with more water during the freezing process (Fort and van Vliet-Lanoe, 2007).

We also observe subsidence rates of up to $-12 \mathrm{~mm} \mathrm{yr}^{-1}$ in the Qugaqie basin and $-25 \mathrm{~mm} \mathrm{yr}^{-1}$ in the Niyaqu basin. Many of those pixels are close to streams and water bod- 
ies. Approximately $30 \%$ in the Niyaqu basin and $60 \%$ in the Qugaqie basin fall into permafrost regions (Zou et al., 2017; Tian et al., 2009). This makes permafrost degradation a potential driver of this subsidence, as a thinning permafrost layer would result in meltwater escaping from the thawing soil. However, longer periods of observation are needed to come up with reliable conclusions.

\subsection{Seasonal displacements in flat terrain}

Both the Niyaqu and the Qugaqie basins have relatively stable flat terrain on a multiannual scale but show a strong seasonal signal in the same areas (Fig. 6a). It is unlikely that this signal is induced by seasonal atmospheric effects, as the amplitude would likely correlate to some degree with relative elevation to the reference points (Dong et al., 2019), which is not the case for our data. The most likely explanation is that this signal represents the heave-subsidence cycle of freezing and thawing of moist soil. Others observed very similar signals over permafrost areas on the northern TP (Daout et al., 2017) and over seasonally frozen ground in Dangxiong county on the southern side of the Nyainqêntanglha range (Li et al., 2015). The heave-subsidence amplitude of these studies agrees well with our results of mostly 3 to $15 \mathrm{~mm}$ in both basins. In similar areas they observe amplitudes of 2.5 to $12 \mathrm{~mm}$ and 10 to $25 \mathrm{~mm}$, respectively. Comparable studies of permafrost landscapes measured thaw subsidence of predominantly 10 to $70 \mathrm{~mm}$ and 2 to $68 \mathrm{~mm}$ per thawing season on Spitsbergen (Rouyet et al., 2019) and in northern Siberia (Antonova et al., 2018), respectively.

In both of our study sites we observe a relation between the amplitude of the heave-subsidence cycle and the DMS (Fig. 5e, f). Areas with high amplitudes tend to reach the DMS later in the year (September to October) and areas with small amplitudes tend to reach their DMS earlier (July to August). The lag time between maximum air temperature and DMS is therefore greater for areas with a large heavesubsidence amplitude. Longer lag times have been associated with a deeper active layer when assuming a one-dimensional heat transfer in soils (Li et al., 2015). For our study areas this would imply that the active layer tends to be deeper near streams and water bodies, as both the heave-subsidence amplitude and the lag time are highest there. This agrees with other studies on active layer thickness, which also observe a deeper active layer in those areas, especially where water bodies remain partially unfrozen in winter (e.g., McKenzie and Voss, 2013).

Other studies observed considerably higher lag times between the highest air temperature and the DMS. They observe lag times of 97 and $65 \mathrm{~d}$ in flat areas (Daout et al., 2017; Li et al., 2015) with longer lag times in mountainous areas, which they attributed to thicker permafrost, colder surroundings and less soil moisture. A small number of the data points of Li et al. (2015) fall within the Qugaqie basin, showing lag times of 50 to $90 \mathrm{~d}$. In the Qugaqie basin we observe no clear median lag time (Fig. 4). It is possible that the difference between their results and ours reflects actual changes to the lag time between their dataset of 2007 to 2011 and ours of 2015 to 2018 , but the point density of their data within the Qugaqie basin is too low to draw reliable conclusions. We determined the lag time by comparing the DMS to the average maximum air temperature at NAMORS from 2010 to 2017. NAMORS is located at an elevation of $4730 \mathrm{~m}$, which is considerably lower than most valley areas of the Qugaqie basin at up to $5600 \mathrm{~m}$. The temperature data acquired by Zhang et al. (2013) within the Qugaqie basin show a maximum air temperature on 27 July, $6 \mathrm{~d}$ later than at NAMORS. Their dataset covers a period of less than 2 years and is therefore likely too short for an accurate comparison but it indicates that the maximum air temperature is similar to that of NAMORS. The Qugaqie basin has a short thaw period, with only 80 to $100 \mathrm{~d}$ in summer reaching daily air temperatures $>0^{\circ}$ (Zhang et al., 2013). Together with the presence of permafrost this may explain the short lag time between the maximum air temperature and the DMS. A short thaw period is associated with a thinner active layer ( $\AA$ kerman and Johansson, 2008), and the cold mountain climate and the permafrost would accelerate the freezing process of the active layer. While this may help to explain the short lag time, it also highlights a major limitation of the model. For the HSM we estimated a sine function for every individual time series to determine the spatial distribution of the heave-subsidence cycle. Areas where this cycle does not follow a sinusoidal pattern are therefore not represented accurately by the HSM. The short thaw period of the Qugaqie basin also shortens the periods of maximum subsidence compared to the periods of maximum heave (Fig. 6a), hence making the heavesubsidence cycle less sinusoidal. Together with the short time series of only 3 to 4 years, this leads to a high shift error of the sine function of $27 \mathrm{~d}$ in the Qugaqie basin and $33 \mathrm{~d}$ in the Niyaqu basin.

The difference of the DMS between ascending and descending datasets is $10 \mathrm{~d}$ in the Qugaqie basin and $27 \mathrm{~d}$ in the Niyaqu basin and not distributed randomly. This is a very high disparity for a displacement with a predominantly vertical direction, which should be represented equally in ascending and descending datasets if the incidence angles are comparable. The difference in incidence angles between the two orbits is $6^{\circ}$ over the Qugaqie basin and $1^{\circ}$ over the Niyaqu basin. Over the Qugaqie basin the resulting difference in sensitivity to vertical displacement and the different number of summer seasons during the observation period (four for ascending and three for descending) may help to explain the $10 \mathrm{~d}$ disparity between ascending and descending datasets. This does not explain the large disparity of $27 \mathrm{~d}$ in the Niyaqu basin, as the difference in incidence angle is very small and the same time period is covered by ascending and descending datasets. For the Niyaqu basin in particular it was necessary to select different reference areas during interferogram generation, as the same areas often did not feature a high coher- 
ence in both orbits. Minor displacement signals of reference areas which were used in only one of the orbits may explain the widespread disparity of the DMS in the Niyaqu basin. The imperfect manner in which the sine curve of the HSM estimates the heave and subsidence of the ground also introduces uncertainties, as this disparity drops to $21 \mathrm{~d}$ in areas of the Niyaqu basin where the explained variation $R^{2}>0.9$ and rises to 29 where $R^{2}<0.6$. The high disparity between the DMS results of ascending and descending datasets and the high shift error of the sine function suggest that the sinusoidal HSM does not produce reliable results of the DMS for such a short time series with only three to four seasons.

\subsection{Multiannual displacements in steep terrain}

Most data points on slopes in both basins show downslope velocities of 8 to $17 \mathrm{~mm} \mathrm{yr}^{-1}$ with a small number of landforms moving faster than $30 \mathrm{~mm} \mathrm{yr}^{-1}$. The instability of most steep terrain is to be expected, as there is very little deep-rooted vegetation to prevent the unconsolidated material from sliding. In our field campaigns we observed that soil-covered slopes, especially in the Niyaqu basin, feature Kobresia pygmaea pastures, which forms a grass mat with a thick root system of up to $30 \mathrm{~cm}$. This may provide some stability in the absence of larger vegetation; however, both climate change and overgrazing are degrading this grass mat (Miehe et al., 2008), which could lead to larger sliding velocities in the future.

When studying relatively fast land surface changes with InSAR, it is important to consider the maximum LOS displacement that can be calculated reliably between two SAR acquisitions. Among other factors this is dependent on the wavelength of the satellite $(5.6 \mathrm{~cm}$ for Sentinel-1) and the temporal baseline of the interferogram. Measurements of displacement exceeding a quarter of the wavelength between two acquisitions are unreliable (Crosetto et al., 2016) and are likely to lead to an underestimation of the displacement signal and low coherence values. This is the case for some of our fast-moving landforms during the summer of 2016, when the temporal baseline is up to $96 \mathrm{~d}$ for the Qugaqie basin in descending orbit. It is therefore likely that we underestimate velocities during that time period. Most interferograms feature much shorter baselines of 12 to $36 \mathrm{~d}$ and are therefore not affected by this issue. It is unlikely that this is the cause of the linear pattern of the fastest landforms, as the temporal baselines of the summer of 2018 are short and also do not show a clear acceleration of the velocity (Fig. 6b). Our data for the Niyaqu basin are less affected by this underestimation of surface velocity, as the maximum temporal baseline is $60 \mathrm{~d}$, and therefore only areas with a LOS velocity greater than $8.5 \mathrm{~cm} \mathrm{yr}^{-1}$ are affected. High velocity reduces coherence values in the center of the fastest landforms and leads to decorrelation in some cases.

We do not observe a clear seasonally accelerated pattern for most of the fastest-moving landforms like rock glaciers. These landforms are creeping at comparatively linear rates, without distinct differences between summer and winter (Fig. 6b), often with multiannual downslope velocities $>50 \mathrm{~mm} \mathrm{yr}^{-1}$. We were able to identify 19 of these landforms in the Niyaqu basin and 33 in the Qugaqie basin by forming clusters of data points with a linear velocity pattern (less than $50 \%$ acceleration of the velocity in summer) and slope velocities $>50 \mathrm{~mm} \mathrm{yr}^{-1}$. Our spatial data coverage of steep slopes is better in the Qugaqie basin compared to the Niyaqu basin. It is therefore unlikely that this 19 to 33 comparison is an accurate reflection of the difference in frequency of these landforms between both study areas. It is likely that some of these clusters have been misidentified as linearly moving, while actually featuring both the seasonal heave-subsidence cycle prevalent in the valleys and the seasonal sliding pattern of the slopes. In some cases those two cycles may cancel each other out to such a degree that the resulting velocity appears linear. This can be observed at the interface between slopes and the valley (Fig. 7a, b).

We determined from optical satellite data, DEM analysis and field observations that $36 \%$ of these linearly creeping clusters are associated with rock glaciers or protalus ramparts, where motion is generally driven by massive ice within the landforms (Whalley and Azizi, 2003). Other studies observe strong seasonal variations in the velocities of rock glaciers (e.g., Kääb and Vollmer, 2000). Rock glacier kinematics are highly dependent on the climatic setting, ice content, ground lithology and slope (Haeberli et al., 2006), making comparison between rock glaciers of different regions difficult. Rock glaciers studied in northwestern Bhutan show velocities of up to $300 \mathrm{~mm} \mathrm{yr}^{-1}$ and in rare cases up to $700 \mathrm{~mm} \mathrm{yr}^{-1}$ (Dini et al., 2019). However, neither study could analyze the seasonal displacement patterns of rock glaciers due to large temporal baselines of their interferograms. Strozzi et al. (2020) observe rock glacier velocities of approximately 1.5 to $2 \mathrm{~m} \mathrm{yr}^{-1}$ in the Argentinian Andes, 2 to $4 \mathrm{~m} \mathrm{yr}^{-1}$ in western Greenland and 1 to $2 \mathrm{~m} \mathrm{yr}^{-1}$ in the Swiss Alps. The former two show a velocity increase of $30 \%$ to $50 \%$ and the latter around $100 \%$ between winter and late summer.

Not all fast and linearly moving areas are associated with landforms containing massive ice. Rock slope instabilities such as rockslides are common on the debris-covered slopes, and while most of them follow a seasonally accelerated displacement pattern, around $24 \%$ of fast and linearly moving areas are likely associated with rock slope instabilities. We can therefore not be certain if fast linear motion is indeed an indicator of displacement driven by massive ice. Their relatively low dependency on seasonality indicates, however, that their displacement is mainly gravity-driven as opposed to slopes with strong seasonal variations, where the displacement is driven by both gravity and freeze-thaw-related processes. 


\subsection{Seasonal displacements in steep terrain}

Most slopes moving at least $10 \mathrm{~mm} \mathrm{yr}^{-1}$ experience a clear seasonal displacement signal, with velocities increasing considerably towards the end of the summer monsoon period (Fig. 6c). Monsoon season is associated with both the highest temperatures and approximately $80 \%$ of the annual precipitation over a period of 4 months from June to September (NAMORS, 2018). For the Qugaqie basin it is also the only time when the average daily air temperature exceeds $0^{\circ} \mathrm{C}$ (Zhang et al., 2013). The clear connection between accelerated surface displacement and the increased air temperature in summer makes freeze-thaw-related processes like solifluction a likely driver of displacements on soil-covered slopes. Solifluction describes a process where seasonal freezing and thawing of the ground induces downslope displacement of up to $1 \mathrm{~m} \mathrm{yr}^{-1}$ (Matsuoka, 2001). Affected slopes in the Qugaqie basin display downslope velocities of mostly 50 to $150 \mathrm{~mm} \mathrm{yr}^{-1}$ and up to $400 \mathrm{~mm} \mathrm{yr}^{-1}$ in some cases towards the end of the summer season.

\section{Conclusion}

Our InSAR time series analysis of Sentinel-1 data clearly shows both multiannual and seasonal surface displacement patterns in the Nam Co area. Most flat areas are relatively stable on a multiannual scale but show a strong seasonal pattern induced by freezing of the active layer in late autumn and winter and its subsequent thawing in spring and summer. This induces a vertical oscillation with an amplitude of 5 to $10 \mathrm{~mm}$ in most regions, with areas near water bodies showing a more pronounced pattern with an amplitude of up to $24 \mathrm{~mm}$. Most steep terrain in both study areas is unstable, due to the unconsolidated material and the lack of deep-rooted vegetation. The terrain moves downslope with velocities of 8 to $17 \mathrm{~mm} \mathrm{yr}^{-1}$. Most steep terrain also shows a seasonal displacement pattern driven by freeze-thaw processes, such as solifluction, on soil-covered slopes and associated with rock slope instabilities, such as rockslides, on debris-covered slopes. Downslope velocities on these slopes accelerate from around $20 \mathrm{~mm} \mathrm{yr}^{-1}$ in winter to 50 to $150 \mathrm{~mm} \mathrm{yr}^{-1}$ in late summer for mean velocities of 30 to $70 \mathrm{~mm} \mathrm{yr}^{-1}$. The fastest landforms can reach mean velocities of 100 to $180 \mathrm{~mm} \mathrm{yr}^{-1}$. These landforms do not follow the seasonally accelerated sliding pattern of most slopes but creep linearly with little difference between summer and winter velocity, indicating that they are gravity-driven. While we have identified some of those landforms as rock glaciers and protalus ramparts, we cannot be certain to which extent fast linear velocity is an indicator for motion driven by massive ice in this area.
Data availability. The data of the surface displacement models presented in this study can be found at https://doi.org/10.1594/PANGAEA.907743 (Reinosch et al., 2020).

Supplement. The supplement related to this article is available online at: https://doi.org/10.5194/tc-14-1633-2020-supplement.

Author contributions. The majority of the scientific writing and the figures were produced by ER. He also performed most of the literature research and data processing. JB performed literature research of the study areas, especially about their geomorphology, and wrote parts of the respective section. Furthermore he proofread the entire document regarding geomorphological and geological data and established connections between the results of the satellite analysis and relevant geomorphological landforms and processes in the field. BR provided guidance regarding InSAR processing and proofreading of the manuscript, with a focus on the technical aspects of InSAR time series analysis. He also secured the funding for this research as part of the TransTiP project. MG proofread a previous version of the manuscript; provided guidance about the relevant research questions, research direction and the manuscript structure; and aided in establishing connections to other remote sensing institutions to discuss the content of this research with fellow researchers. JB secured funding for the project, evaluated potential study areas and provided us with additional data through additional proposals to the DLR. JD performed a review of the methods used with a focus on the seasonal displacement signal present in our data and the potential causes thereof.

Competing interests. The authors declare that they have no conflict of interest.

Acknowledgements. We would like to thank the DLR for providing us with the high-resolution TanDEM-X DEM for our data processing (proposal ID DEM_HYDR1727) and the ESA and Copernicus for making Sentinel-1 and Sentinel-2 data freely available to the public.

Financial support. This research has been supported by the Deutsche Forschungsgemeinschaft (grant no. GRK 2309/1).

This open-access publication was funded by Technische Universität Braunschweig.

Review statement. This paper was edited by Christian Hauck and reviewed by two anonymous referees. 


\section{References}

Åkerman, H. J. and Johansson, M.: Thawing permafrost and thicker active layers in sub-arctic Sweden, Permafrost Periglac., 19, 279-292, https://doi.org/10.1002/ppp.626, 2008.

Antonova, S., Sudhaus, H., Strozzi, T., Zwieback, S., Kääb, A., Heim, B., Langer, M., Bornemann N., and Boike, J.: Thaw subsidence of a Yedoma landscape in northern Siberia, measured in situ and estimated from TerraSAR-X interferometry, Remote Sens., 10, 494, https://doi.org/10.3390/rs10040494, 2018.

Bateson, L., Cigna, F., Boon, D., and Sowter, A.: The application of the Intermittent SBAS (ISBAS) InSAR method to the South Wales Coalfield, UK, Int. J. Appl. Earth Observ. Geoinf., 34, 249-257, https://doi.org/10.1016/j.jag.2014.08.018, 2015.

Bauer, A., Paar, G., and Kaufmann, V.: Terrestrial laser scanning for rock glacier monitoring, in: 8th International Conference on Permafrost, Proceedings, vol. 1, 55-60, 2003.

Berardino, P., Fornaro, G., Lanari, R., and Sansosti, E.: A new algorithm for surface deformation monitoring based on small baseline differential SAR interferograms, IEEE T. Geosci. Remote, 40, 2375-2383, https://doi.org/10.1109/TGRS.2002.803792, 2002.

Böhme, M., Bunkholt, H. S. S., Oppikofer, T., Dehls, J. F., Hermanns, R. L., Eriksen, H. Ø., Laukens, T. R., and Eiken, T.: Using 2D InSAR, dGNSS and structural field data to understand the deformation mechanism of the unstable rock slope Gamanjunni 3, northern Norway, in: Landslides and Engineered Slopes, Experience, Theory and Practice, CRC Press, 443-449, 2016.

Bolch, T., Yao, T., Kang, S., Buchroithner, M. F., Scherer, D., Maussion, F., Huintjes, E., and Schneider, C.: A glacier inventory for the western Nyainqentanglha Range and the Nam Co Basin, Tibet, and glacier changes 1976-2009, The Cryosphere, 4, 419433, https://doi.org/10.5194/tc-4-419-2010, 2010.

Crosetto, M., Monserrat, O., Cuevas-González, M., Devanthéry, N., and Crippa, B.: Persistent scatterer interferometry: A review, ISPRS J. Photogramm., 115, 78-89, https://doi.org/10.1016/j.isprsjprs.2015.10.011, 2016.

Daanen, R. P., Grosse, G., Darrow, M. M., Hamilton, T. D., and Jones, B. M.: Rapid movement of frozen debris-lobes: implications for permafrost degradation and slope instability in the south-central Brooks Range, Alaska, Nat. Hazards Earth Syst. Sci., 12, 1521-1537, https://doi.org/10.5194/nhess12-1521-2012, 2012.

Daout, S., Doin, M. P., Peltzer, G., Socquet, A., and Lasserre, C.: Large-scale InSAR monitoring of permafrost freeze-thaw cycles on the Tibetan Plateau, Geophys. Res. Lett., 44, 901-909, https://doi.org/10.1002/2016GL070781, 2017.

Dini, B., Daout, S., Manconi, A., and Loew, S.: Classification of slope processes based on multitemporal DInSAR analyses in the Himalaya of NW Bhutan, Remote Sens. Environ., 233, 111408, https://doi.org/10.1016/j.rse.2019.111408, 2019.

Dong, J., Zhang, L., Liao, M., and Gong, J.: Improved correction of seasonal tropospheric delay in InSAR observations for landslide deformation monitoring. Remote Sens. Environ., 233, 111370, https://doi.org/10.1016/j.rse.2019.111370, 2019.

Eriksen, H. Ø., Lauknes, T. R., Larsen, Y., Corner, G. D., Bergh, S. G., Dehls, J., and Kierulf, H. P.: Visualizing and interpreting surface displacement patterns on unstable slopes using multi-geometry satellite SAR interferom- etry (2D InSAR), Remote Sens. Environ., 191, 297-312, https://doi.org/10.1016/j.rse.2016.12.024, 2017.

ESA (European Space Agency): SENTINEL-1, ESA's Radar Observatory Mission for GMES Operational Services, ESA SP-1322/1, Noordwijk, 2012.

Fischer, L., Kääb, A., Huggel, C., and Noetzli, J.: Geology, glacier retreat and permafrost degradation as controlling factors of slope instabilities in a high-mountain rock wall: the Monte Rosa east face, Nat. Hazards Earth Syst. Sci., 6, 761-772, https://doi.org/10.5194/nhess-6-761-2006, 2006.

Fort, F. and van Vliet-Lanoe, B.: Permafrost and periglacial environment of Western Tibet, Landform Analysis, 5, 25-29, 2007.

French, H. M.: The periglacial environment, 4th edn., John Wiley \& Sons, Chichester, England, 2017.

Haeberli, W., Hallet, B., Arenson, L., Elconin, R., Humlum, O., Kääb, A., Kaufmann, V., Ladanyi, B., Matsuoka, N., Springmann, S., and Mühll, D. V.: Permafrost creep and rock glacier dynamics, Permafrost Periglac., 17, 189-214, https://doi.org/10.1002/ppp.561, 2006.

Jarvis, A., Reuter, H. I., Nelson, A., and Guevara, E.: Hole-filled SRTM for the globe Version 4, International Centre for Tropical Agriculture (CIAT), available at http://srtm.csi.cgiar.org (last access: 29 July 2019), 2008.

Jiang, L., Nielsen, K., Andersen, O. B., and Bauer-Gottwein, P.: Monitoring recent lake level variations on the Tibetan Plateau using CryoSat-2 SARIn mode data, J. Hydrology, 544, 109-124, https://doi.org/10.1016/j.jhydrol.2016.11.024, 2017.

Jones, D. B., Harrison, S., Anderson, K., and Whalley, W. B.: Rock glaciers and mountain hydrology: A review, Earth-Sci. Rev., https://doi.org/10.1016/j.earscirev.2019.04.001, 2019.

Joshi, N., Baumann, M., Ehammer, A., Fensholt, R., Grogan, K., Hostert, P., Jepsen, R. J., Kuemmerle, T., Meyfroidt, P., Mitchard, E. T. A., Reiche, J. Ryan, C. M., and Waske, B.: A review of the application of optical and radar remote sensing data fusion to land use mapping and monitoring, Remote Sens., 8, 70, https://doi.org/10.3390/rs8010070, 2016.

Kääb, A.: Remote sensing of permafrost-related problems and hazards, Permafrost Periglac., 19, 107-136, https://doi.org/10.1002/ppp.619, 2008.

Kääb, A., and Vollmer, M.: Surface geometry, thickness changes and flow fields on creeping mountain permafrost: automatic extraction by digital image analysis, Permafrost Periglac., 11, 315-326, https://doi.org/10.1002/10991530(200012)11:4<315::AID-PPP365>3.0.CO;2-J, 2000.

Kapp, J. L. D. A., Harrison, T. M., Kapp, P., Grove, M., Lovera, O. M., and Lin, D.: Nyainqentanglha Shan: a window into the tectonic, thermal, and geochemical evolution of the Lhasa block, southern Tibet, J. Geophys. Res.-Sol. Ea., 110, B08413, https://doi.org/10.1029/2004JB003330, 2005.

Keil, A., Berking, J., Mügler, I., Schütt, B., Schwalb, A., and Steeb, P.: Hydrological and geomorphological basin and catchment characteristics of Lake Nam Co, South-Central Tibet, Quatern. Int., 218, 118-130, https://doi.org/10.1016/j.quaint.2009.02.022, 2010.

Kneisel, C., Rödder, T., and Schwindt, D.: Frozen ground dynamics resolved by multi-year and year-round electrical resistivity monitoring at three alpine sites in the Swiss Alps, Near Surf. Geophys., 12, 117-132, https://doi.org/10.3997/1873-0604.2013067, 2014. 
Kropáček, J., Braun, A., Kang, S., Feng, C., Ye, Q., and Hochschild, V.: Analysis of lake level changes in Nam Co in central Tibet utilizing synergistic satellite altimetry and optical imagery, Int. J. Appl. Earth Observ. Geoinfo., 17, 3-11, https://doi.org/10.1016/j.jag.2011.10.001, 2012.

Lei, Y., Yao, T., Bird, B. W., Yang, K., Zhai, J., and Sheng, Y.: Coherent lake growth on the central Tibetan Plateau since the 1970s: Characterization and attribution, J. Hydrol., 483, 61-67, https://doi.org/10.1016/j.jhydrol.2013.01.003, 2013.

Li, Z. W., Xu, W. B., Feng, G. C., Hu, J., Wang, C. C., Ding, X. L., and Zhu, J. J.: Correcting atmospheric effects on InSAR with MERIS water vapour data and elevationdependent interpolation model, Geophys. J. Int., 189, 898-910, https://doi.org/10.1111/j.1365-246X.2012.05432.x, 2012.

Li, B., Yu, Z., Liang, Z., and Acharya, K.: Hydrologic response of a high altitude glacierized basin in the central Tibetan Plateau, Glob. Planet. Change, 118, 69-84, https://doi.org/10.1016/j.gloplacha.2014.04.006, 2014.

Li, Z., Zhao, R., Hu, J., Wen, L., Feng, G., Zhang, Z., and Wang, Q.: InSAR analysis of surface deformation over permafrost to estimate active layer thickness based on onedimensional heat transfer model of soils, Sci. Rep., 5, 15542, https://doi.org/10.1038/srep15542, 2015.

Li, Q.: Spatial variability and long-term change in pollen diversity in Nam Co catchment (central Tibetan Plateau): Implications for alpine vegetation restoration from a paleoecological perspective, Science China Earth Sciences, 61, 270-284, https://doi.org/10.1007/s11430-017-9133-0, 2018.

Liu, L., Millar, C. I., Westfall, R. D., and Zebker, H. A.: Surface motion of active rock glaciers in the Sierra Nevada, California, USA: inventory and a case study using InSAR, The Cryosphere, 7, 1109-1119, https://doi.org/10.5194/tc-7-1109-2013, 2013.

Matsuoka, N.: Solifluction rates, processes and landforms: a global review, Earth-Sci. Rev., 55, 107-134, https://doi.org/10.1016/S0012-8252(01)00057-5, 2001.

Matsuoka, N., Abe, M., and Ijiri, M.: Differential frost heave and sorted patterned ground: field measurements and a laboratory experiment, Geomorphology, 52, 73-85, https://doi.org/10.1016/S0169-555X(02)00249-0, 2003.

McKenzie, J. M. and Voss, C. I.: Permafrost thaw in a nested groundwater-flow system, Hydrogeol. J., 21, 299-316, https://doi.org/10.1007/s10040-012-0942-3, 2013.

Messerli, B., Viviroli, D., and Weingartner, R.: Mountains of the World: Vulnerable Water Towers for the 21st Century, AMBIO, 2004, 29-34, 2004.

Miehe, G., Miehe, S., Kaiser, K., Jianquan, L., and Zhao, X.: Status and dynamics of the Kobresia pygmaea ecosystem on the Tibetan Plateau, AMBIO, 37, 272-280, https://doi.org/10.1579/00447447(2008)37[272:SADOTK]2.0.CO;2, 2008.

Müller, J., Vieli, A., and Gärtner-Roer, I.: Rock glaciers on the run - understanding rock glacier landform evolution and recent changes from numerical flow modeling, The Cryosphere, 10, 2865-2886, https://doi.org/10.5194/tc-10-2865-2016, 2016.

NAMORS: Meteorological Data for the NAMORS research station, 2010 to 2017, Institute of Tibetan Plateau Research, Chinese Academy of Sciences, Lhasa, available at: https://data.tpdc.ac. cn/en/data/4deeb2b4-4fc1-4c7c-b0c6-6263a547d53f/, last access: 4 May 2018.
Notti, D., Herrera, G., Bianchini, S., Meisina, C., García-Davalillo, J. C., and Zucca, F.: A methodology for improving landslide PSI data analysis, Int. J. Remote Sens., 35, 2186-2214, https://doi.org/10.1080/01431161.2014.889864, 2014.

Osmanoğlu, B., Sunar, F., Wdowinski, S., and CabralCano, E.: Time series analysis of InSAR data: Methods and trends, ISPRS J. Photogramm., 115, 90-102, https://doi.org/10.1016/j.isprsjprs.2015.10.003, 2016.

Reinosch, E., Buckel, J., Dong, J., Gerke, M., Baade, J., and Riedel, B.: Surface displacement and velocity models at Lake NamCo (Tibetan Plateau) derived from Sentinel1 data via InSAR time series analysis, PANGAEA, https://doi.org/10.1594/PANGAEA.907743, 2020.

Riseborough, D., Shiklomanov, N., Etzelmüller, B., Gruber, S., and Marchenko, S.: Recent advances in permafrost modelling, Permafrost Periglac., 19, 137-156, https://doi.org/10.1002/ppp.615, 2008.

Rouyet, L., Lauknes, T. R., Christiansen, H. H., Strand, S. M., and Larsen, Y.: Seasonal dynamics of a permafrost landscape, Adventdalen, Svalbard, investigated by InSAR, Remote Sens. Environ., 231, 111236, https://doi.org/10.1016/j.rse.2019.111236, 2019.

Schuur, E. A., McGuire, A. D., Schädel, C., Grosse, G., Harden, J. W., Hayes, D. J., Hugelius, G., Koven, C. D., Kuhry, P., Lawrence, D. M., Natali, S. M., Olefeldt, D., Romanovsky, V. E., Schaefer, K., Turetsky, M. R., Treat, C. C., and Vonk, J. E.: Climate change and the permafrost carbon feedback, Nature, 520, 171-179, https://doi.org/10.1038/nature14338, 2015.

Shur, Y., Hinkel, K. M., and Nelson, F. E.: The transient layer: implications for geocryology and climate-change science, Permafrost Periglac., 16, 5-17, https://doi.org/10.1002/ppp.518, 2005.

Song, C., Huang, B., Ke, L., and Richards, K. S.: Seasonal and abrupt changes in the water level of closed lakes on the Tibetan Plateau and implications for climate impacts, J. Hydrol., 514, 131-144, https://doi.org/10.1016/j.jhydrol.2014.04.018, 2014.

Sowter, A., Bateson, L., Strange, P., Ambrose, K., and Syafiudin, M. F.: DInSAR estimation of land motion using intermittent coherence with application to the South Derbyshire and Leicestershire coalfields, Remote Sens. Lett., 4, 979-987, https://doi.org/10.1080/2150704X.2013.823673, 2013.

Strozzi, T., Caduff, R., Jones, N., Barboux, C., Delaloye, R., Bodin, X., Kääb, A., Mätzler, E., and Schrott, L.: Monitoring Rock Glacier Kinematics with Satellite Synthetic Aperture Radar, Remote Sens., 12, 559, https://doi.org/10.3390/rs12030559, 2020.

Tian, K., Liu, J., Kang, S., Campbell, I. B., Zhang, F., Zhang, Q., and $\mathrm{Lu}, \mathrm{W}$.: Hydrothermal pattern of frozen soil in Nam Co lake basin, the Tibetan Plateau, Environ. Geol., 57, 1775-1784, https://doi.org/10.1007/s00254-008-1462-2, 2009.

Wang, X., Liu, L., Zhao, L., Wu, T., Li, Z., and Liu, G.: Mapping and inventorying active rock glaciers in the northern Tien Shan of China using satellite SAR interferometry, The Cryosphere, 11, 997-1014, https://doi.org/10.5194/tc-11-997-2017, 2017.

Wessel, B., Huber, M., Wohlfart, C., Marschalk, U., Kosmann, D., and Roth, A.: Accuracy assessment of the global TanDEM-X Digital Elevation Model with GPS data, ISPRS J. Photogramm., 139, 171-182, https://doi.org/10.1016/j.isprsjprs.2018.02.017, 2018. 
Whalley, W. B. and Azizi, F.: Rock glaciers and protalus landforms: Analogous forms and ice sources on Earth and Mars. J. Geophys. Res.-Planet., 108, 8032, https://doi.org/10.1029/2002JE001864, 2003.

Wu, Q., Zhang, T., and Liu, Y.: Permafrost temperatures and thickness on the Qinghai-Tibet Plateau, Global Planet. Change, 72, 32-38, https://doi.org/10.1016/j.gloplacha.2010.03.001, 2010.

Yagüe-Martínez, N., Prats-Iraola, P., Gonzalez, F. R., Brcic, R., Shau, R., Geudtner, D., Eineder, M., and Bamler, R.: Interferometric processing of Sentinel-1 TOPS data, IEEE T. Geosci. Remote, 54, 2220-2234, https://doi.org/10.1109/TGRS.2015.2497902, 2016.

Yao, T., Liu, X., Wang, N., and Shi, Y.: Amplitude of climatic changes in Qinghai-Tibetan Plateau, Chinese Sci. Bull., 45, 1236-1243, https://doi.org/10.1007/BF02886087, 2000.

Yao, T., Pu, J., Lu, A., Wang, Y., and Yu, W.: Recent glacial retreat and its impact on hydrological processes on the Tibetan Plateau, China, and surrounding regions, Arct. Antarct. Alp. Res., 39, 642-650, https://doi.org/10.1657/1523-0430(07510)[YAO]2.0.CO;2, 2007.

Yao, T., Masson-Delmotte, V., Gao, J., Yu, W., Yang, X., Risi, C., Sturm, C., Werner, M., Zhao, H., He, Y., Ren, W., Tian, L., Shi, C., and Hou, S.: A review of climatic controls on $\delta^{18} \mathrm{O}$ in precipitation over the Tibetan Plateau: Observations and simulations, Rev. Geophys., 51, 525-548, https://doi.org/10.1002/rog.20023, 2013.

Ye, Q., Zong, J., Tian, L., Cogley, J. G., Song, C., and Guo, W.: Glacier changes on the Tibetan Plateau derived from Landsat imagery: mid-1970s - 2000-13, J. Glaciol., 63, 273-287, https://doi.org/10.1017/jog.2016.137, 2017.

Yu, Z., Wu, G., Keys, L., Li, F., Yan, N., Qu, D., and Liu, X.: Seasonal variation of chemical weathering and its controlling factors in two alpine catchments, Nam Co basin, central Tibetan Plateau, J. Hydrol., 576, 381-395, https://doi.org/10.1016/j.jhydrol.2019.06.042, 2019.
Zhang, G., Kang, S., Fujita, K., Huintjes, E., Xu, J., Yamazaki, T., Haginoya, S., Wei, Y., Scherer, D., Schneider, C., and Yao, T.: Energy and mass balance of Zhadang glacier surface, central Tibetan Plateau, J. Glaciol., 59, 137-148, https://doi.org/10.3189/2013JoG12J152, 2013.

Zhang, G., Li, J., and Zheng, G.: Lake-area mapping in the Tibetan Plateau: an evaluation of data and methods, Int. J. Remote Sensing, 38, 742-772, https://doi.org/10.1080/01431161.2016.1271478, 2017.

Zhang, Y. and Michalowski, R. L.: Thermal-hydro-mechanical analysis of frost heave and thaw settlement, J. Geotech. Geoenviron., 141, 04015027, https://doi.org/10.1061/(ASCE)GT.19435606.0001305, 2015.

Zhao, R., Li, Z. W., Feng, G. C., Wang, Q. J., and Hu, J.: Monitoring surface deformation over permafrost with an improved SBAS-InSAR algorithm: With emphasis on climatic factors modeling, Remote Sens. Environ., 184, 276-287, https://doi.org/10.1016/j.rse.2016.07.019, 2016.

Zhou, S., Kang, S., Chen, F., and Joswiak, D. R.: Water balance observations reveal significant subsurface water seepage from Lake Nam Co, south-central Tibetan Plateau, J. Hydrol., 491, 89-99, https://doi.org/10.1016/j.jhydrol.2013.03.030, 2013.

Zink, M., Bachmann, M., Bräutigam, B., Fritz, T., Hajnsek, I., Moreira, A., Wessel, B., and Krieger, G.: TanDEM-X: The New Global DEM Takes Shape, IEEE Geosci. Remote S., 2, 8-23, https://doi.org/10.1109/MGRS.2014.2318895, 2014.

Zou, D., Zhao, L., Sheng, Y., Chen, J., Hu, G., Wu, T., Wu, J., Xie, C., Wu, X., Pang, Q., Wang, W., Du, E., Li, W., Liu, G., Li, J., Qin, Y., Qiao, Y., Wang, Z., Shi, J., and Cheng, G.: A new map of permafrost distribution on the Tibetan Plateau, The Cryosphere, 11, 2527-2542, https://doi.org/10.5194/tc-11-2527-2017, 2017.

Zwieback, S., Hensley, S., and Hajnsek, I.: Soil moisture estimation using differential radar interferometry: Toward separating soil moisture and displacements, IEEE T. Geoscience Remote, 55, 5069-5083, https://doi.org/10.1109/TGRS.2017.2702099, 2017. 